\title{
Vapor Space Characterization of Waste Tank 241-BY-106: Results from Samples Collected Through the Vapor Sampling System on 7/8/94
}

\author{
R. B. Lucke \\ K. H. Pool, Ph.D. \\ M. W. Ligotke \\ T. W. Clauss \\ B. D. McVeety, Ph.D. \\ J. S. Fruchter, Ph.D. \\ S. C. Goheen, Ph.D.
}

October 1995

Prepared for

Westinghouse Hanford Company under a Related Services Agreement with the U.S. Department of Energy

Contract DE-AC06-76RLO 1830

Pacific Northwest Laboratory

Richland, Washington 99352 
$\therefore \cdot$

$\therefore$ $\frac{3}{3}:$ 


\section{DISCLAIMER}

This report was prepared as an account of work sponsored by an agency of the United States Government. Neither the United States Government nor any agency thereof, nor any of their employees, make any warranty, express or implied, or assumes any legal liability or responsibility for the accuracy, completeness, or usefulness of any information, apparatus, product, or process disclosed, or represents that its use would not infringe privately owned rights. Reference herein to any specific commercial product, process, or service by trade name, trademark, manufacturer, or otherwise does not necessarily constitute or imply its endorsement, recommendation, or favoring by the United States Government or any agency thereof. The views and opinions of authors expressed herein do not necessarily state or reflect those of the United States Government or any agency thereof. 


\section{DISCLAIMER}

Portions of this document may be illegible in electronic image products. Images are produced from the best available original document. 


\section{Summary}

This report describes organic and inorganic analyses results from tank-headspace samples collected from the Hanford single-shell waste storage Tank 241-BY-106 (referred to as Tank BY-106). Quantitative results were obtained for $\mathrm{NH}_{3}, \mathrm{NO}_{\mathrm{x}}$, and $\mathrm{H}_{2} \mathrm{O}$. A summary of the results for inorganic analytes is listed in Summary Table 1.

\section{Summary Table 1. Summary Results of Inorganic Analytes from Samples Collected from the Tank Headspace of Tank BY-106 on 7/7/94}

\begin{tabular}{lc} 
Analyte & Concentration \\
\cline { 2 - 2 } $\mathrm{NH}_{3}$ & $74 \pm 2 \mathrm{ppmv}^{(\mathrm{a})}$ \\
$\mathrm{NO}^{\mathrm{NO}}$ & $0.16 \pm 0.06 \mathrm{ppmv}_{2}(\mathrm{a})$ \\
$\mathrm{H}_{2} \mathrm{O}$ & $0.05 \pm 0.04 \mathrm{ppmv}^{(\mathrm{a})}$
\end{tabular}

(a) See Section 2.4. NO values are from sorbent-trap sections that were not protected by $\mathrm{NH}_{3}$ sorbent traps.

Organic analytes that are listed in U.S. Environmental Protection Agency (EPA) compendium Method TO-14 were quantitatively determined. Of these only a few were observed above the 2-ppbv detection limits. These are summarized in Table 3.1 Approximately 50 tentatively identified compounds (TICs) not listed in EPA compendium Method TO-14 were observed above the detection limit of (ca.) 10 ppbv. Standards for the TICs were not available at the time of analysis. The tentative identification of these analytes and their estimated semi-quantitative concentrations in the samples are provided in Table 3.2, which shows quantities of all TICs above the concentration of ca. $10 \mathrm{ppbv}$. This consists of more than 50 organic analytes. The 7 organic analytes with the highest estimated concentrations are shown in Summary Table 2. These 7 analytes account for approximately $50 \%$ of the total organic components in Tank BY-106 and are reported from the average of three SUMMA ${ }^{\mathrm{TM}}$ canister samples. Detailed descriptions of the results appear in the text. Unlike tanks previously studied, normal paraffin hydrocarbons did not contribute significantly to the total organic concentration of the tank headspace of Tank BY-106. The total concentration of TICs detected in the tank-headspace samples was also much lower than that seen in other tanks ${ }^{(a)}$. The average of three SUMMATM canister samples was $130 \mathrm{mg} / \mathrm{m}^{3}$. This concentration is approximately $10 \%$ of the concentration of organic material in the vapor of Tank C103 (Huckaby and Story 1994).

(a) Analysis reports for Tanks BY-104, BY-108, and BY-107 are presently being prepared for Pacific Northwest Laboratory clearance. 


$\begin{array}{cc}\begin{array}{c}\text { Summary Table 2. Summary Results of Selected Organic Analytes } \\ \begin{array}{c}\text { Selected } \\ \text { Organic Analytes (TIC) }\end{array}\end{array} & \begin{array}{c}\text { Average } \\ \text { Concentrations }\left(\mathrm{mg} / \mathrm{m}^{3}\right)\end{array} \\ \text { Propene } & 1 \\ \text { 2-Methyl-1-propene } & 1 \\ \text { n-Butane } & 1 \\ \text { Acetone } & 1 \\ \text { n-Pentane } & 1 \\ \text { 1-Butanol } & 1 \\ \text { Trichlorofluoromethane } & 1\end{array}$

\section{Reference}

Huckaby, J. L. and M. S. Story. 1994. Vapor Characterization of Tank 241-C-103. WHC-EP-0780. Westinghouse Hanford Company, Richland, Washington. 


\section{Acknowledgments}

The authors gratefully acknowledge the support of other project staff at Pacific Northwest Laboratory who contributed to the successful completion of this sampling and analysis activity. Jeff Edwards served as the PNL single-point-of-contact and coordinated sample handling and communications with Westinghouse Hanford Company. Jeff also supported work in the organic analytical laboratory. Amit Sharma assisted in the organic analytical laboratory and assisted in preparing this report. Bruce Lerner performed method development and validation work that supported the inorganic vapor sampling. Sally Slate and May-Lin Thomas analyzed inorganic samples, and Annalisa Krupsha and Gary Dennis prepared the solid-sorbent sample trains. Georgia Ruebsamen provided word processing support. 
-... 


\section{Abbreviations}

$\begin{array}{ll}\text { COC } & \text { chain of custody } \\ \text { C }_{\mathrm{v}} & \text { concentration by volume } \\ \text { DIW } & \text { deionized water } \\ \text { emf } & \text { electromotive force } \\ \text { EPA } & \text { U.S. Environmental Protection Agency } \\ \text { GC/MS } & \text { gas chromatography/mass spectrometry } \\ \text { HP } & \text { Hewlett Packard } \\ \text { IC } & \text { ion chromatography } \\ \text { IL } & \text { impact level } \\ \text { MDL } & \text { minimum detection limit } \\ \text { NIST } & \text { National Institute for Standards and Technology } \\ \text { NPH } & \text { normal paraffin hydrocarbon } \\ \text { OSHA } & \text { Occupational Safety and Health Administration } \\ \text { PFA } & \text { perflouroalkoxy } \\ \text { PNL } & \text { Pacific Northwest Laboratory } \\ \text { ppbv } & \text { part-per-billion by volume } \\ \text { ppmv } & \text { part-per-million by volume } \\ \text { QA } & \text { quality assurance } \\ \text { REL } & \text { recommended exposure limit } \\ \text { SCIC } & \text { suppressed-conductivity ion chromatography } \\ \text { SIE } & \text { selective ion electrode } \\ \text { SRM } & \text { standard reference material } \\ \text { STP } & \text { standard temperature and pressure } \\ \text { TEA } & \text { triethanolamine } \\ \text { TIC } & \text { tentatively identified compound } \\ \text { VSS } & \text { vapor sampling system } \\ \text { WHC } & \text { Westinghouse Hanford Company } \\ & \end{array}$




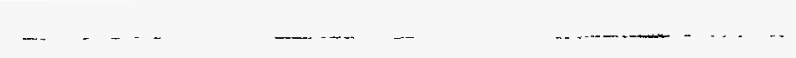




\section{Contents}

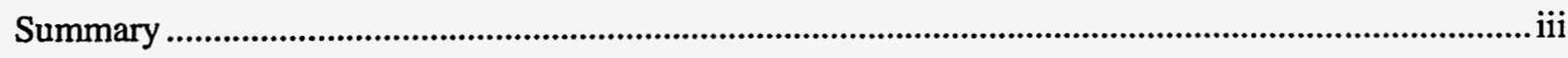

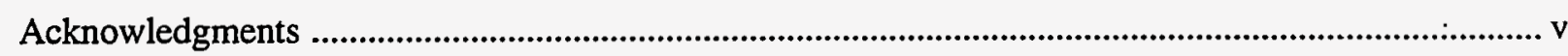

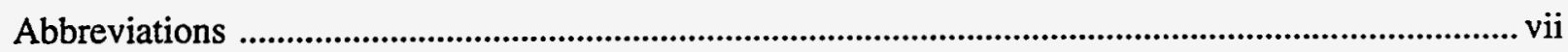

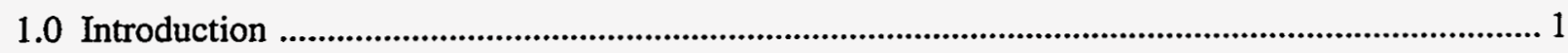

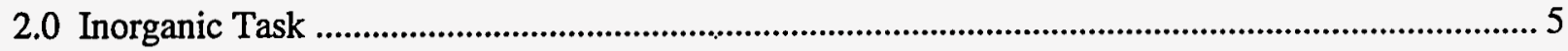

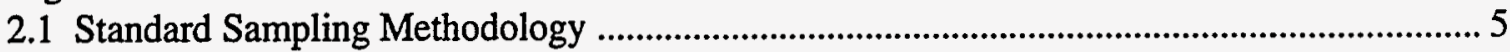

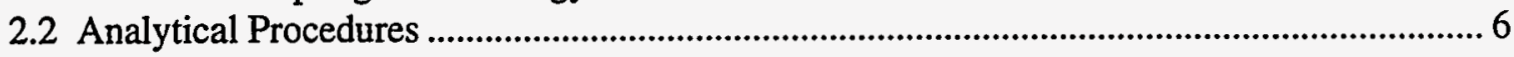

2.3 Quality Assurance/Quality Control ................................................................................. 7

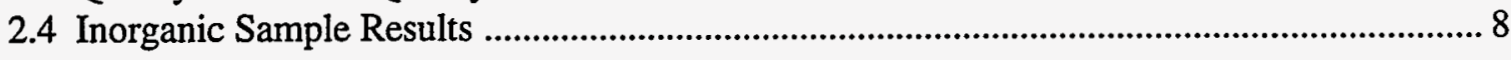

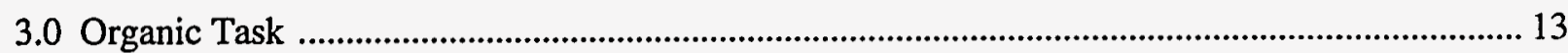

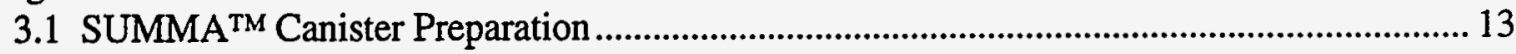

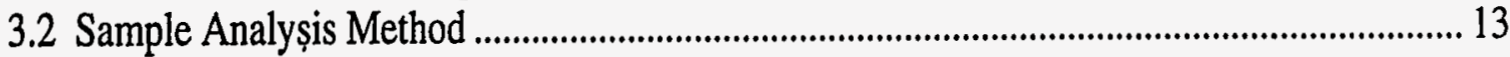

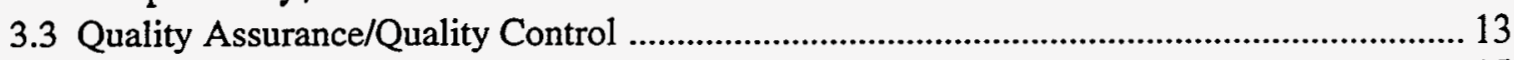

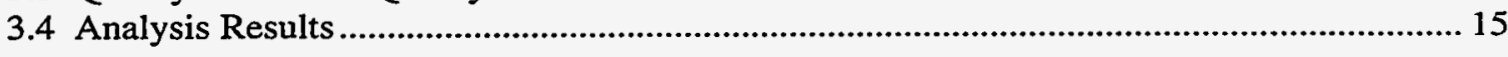

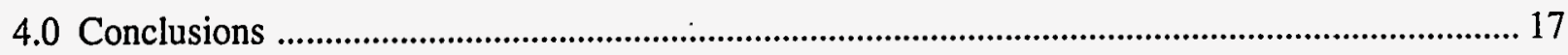

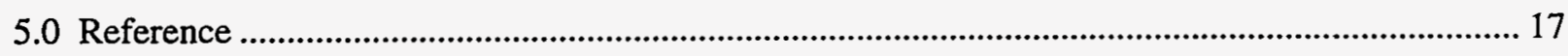

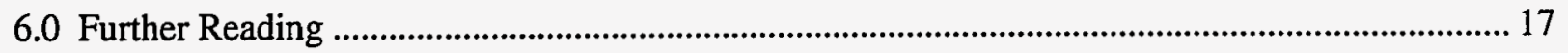




\section{Tables}

2.1 Analysis Procedures and Detection Limits of Target Inorganic Analytes ................................ 8

2.2 List of PNL Inorganic Samples and Gravimetric Results Obtained from

a Heated Tube Inserted in the Tank Headspace of Tank BY-106 on 7/8/94 …........................... 9

2.3 Percentage Recovery Results of Inorganic Spiked blanks Sent to the Field but not Opened During Sampling of Tanks BY-104, -105, and -106 in

June and July, 1994 10

2.4 Inorganic Vapor Sample Results Obtained From a Heated Tube Inserted in the Tank Headspace of Tank BY-106 on 7/8/94

3.1 TO-14 Analysis Results for Samples Collected from Hanford Waste Tank BY-106 in SUMMA ${ }^{\text {TM }}$ Canisters on 7/8/94 18

3.2 Table of Tentatively Identified Compounds and Estimated Concentrations in Hanford in Waste Tank 241-BY-106 SUMMA ${ }^{\text {TM }}$ Canister Collected on 7/8/94 19

3.3 Estimated Concentration in Ambient SUMMA ${ }^{\text {TM }}$ Canister Samples Taken for VSS Cleanliness Comparison 21

\section{Figures}

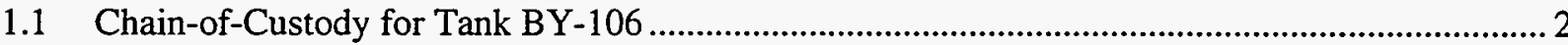

3.1 GC/MS Chromatogram of Hanford Waste Tank BY-106 SUMMA ${ }^{\text {TM }}$

Canister Vapor Sample S4021-A05-027 Collected Through the WHC Vapor Sampling System on 7/8/94 


\subsection{Introduction}

This report describes results of the analysis of tank headspace samples taken from the Hanford waste Tank 241-BY-106 (referred to as Tank BY-106) on July 8, 1994. The samples were collected using the Westinghouse Hanford Company (WHC) vapor sampling system (VSS). The WHC sample job number was S4021. (Figure 1). These results are expected to be used to estimate the potential toxicity of tank-headspace gas as described in Data Quality Objectives for Generic in-Tank Health and Safety Vapor Issue Resolution (WHC-SD-WM-DQO-002, Rev 0).

Sampling devices, including sorbent tubes (for inorganic analyses), and SUMMA ${ }^{\mathrm{TM}}$ canisters (for organic analysis) were supplied to the WHC sampling staff on June 20,1994. Samples were taken (by WHC) on July 8 and were returned from the field on July 11. Inorganic (sorbent tube) samples delivered to Pacific Northwest Laboratory (PNL) ${ }^{(a)}$ on chain of custody (COC) 006895 (Figure 1.1a) included 16 multi-sorbent trap samples as described in Tables 2.2, 2.3, and 2.4. Five SUMMA ${ }^{\mathrm{TM}}$ samples delivered to PNL on COC 006898 (Figure 1.1b), included one ambient-air sample through the VSS, one ambient-air sample without the VSS and three tank-headspace SUMMA ${ }^{T M}$ canister samples through the VSS.

The samples were inspected upon delivery to the 326/23B laboratory and logged into PNL record book 55408 as per PNL Technical Procedure PNL-TVP- $07^{(b)}$. Custody of the sorbent tubes was transferred to PNL personnel performing the inorganic analysis and stored at refrigerated $\left(4^{\circ} \mathrm{C}\right)$ temperature until the time of analysis. The canisters were stored in the 326/23B laboratory at ambient $\left(25^{\circ} \mathrm{C}\right)$ temperature until the time of analysis. Access to the 326/23B laboratory is limited to PNL personnel working on the waste-tank safety program. Analyses described in this report were performed at PNL in the 300 area of the Hanford Reservation. Analytical methods that were used are described in the text. In summary, sorbent tubes for inorganic analyses containing sample materials were either weighed (for water analysis) or desorbed with water (for ammonia or $\mathrm{NO}_{\mathrm{x}}$ analyses). The water extracts were analyzed either by selective electrode or by ion chromatography (IC). Organic analyses were performed using gas chromatography/mass spectrometry (GC/MS).

(a) Pacific Northwest Laboratory is operated for the U.S. Department of Energy by Battelle Memorial Institute under Contract DE-AC06-76RLO 1830.

(b) PNL-TVP-07 (rev. 0), 2/94, Sample Shipping and Receiving Procedure for PNL Waste Tank Samples, PNL Technical DRAFT Procedure, Pacific Northwest Laboratory, Richland, Washington. 


\begin{tabular}{|c|c|c|}
\hline $\begin{array}{l}\text { Westinghouse } \\
\text { Hanford Company }\end{array}$ & CHAIN OF CUSTODY & WHC 006895 \\
\hline Custody Form Iniliator & J. A. Edwards & $\begin{array}{rr}(509) 373 & -0141 \\
85-3009\end{array}$ \\
\hline Company Contact & R. Westberg & (509) $\quad 373-5734$ \\
\hline $\begin{array}{l}\text { Project Designation/Sampling } \\
\text { BY } 106 \text { Tank Vapor } \$ \\
\text { Ice Chest No. }\end{array}$ & $\begin{array}{l}\text { cations } 200 \text { East Tank Farm } \\
\text { nple SAF S4021 } \\
\text { (VSS Truck) }\end{array}$ & 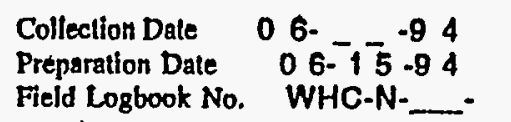 \\
\hline Bill or Lading/Nirbill No. & N/A & Orrsite Property No. N/A \\
\hline Method of Shipment & Government Truck & Sample Job \# \\
\hline
\end{tabular}

Shipped to

PNL?

Possible Sample Hazards/Remarks Unknown at time of sampling

Sample Identification

\begin{tabular}{|c|c|}
\hline $\begin{array}{l}\text { S4021 - A16. W64 } \\
\text { S4021 - A17 : W65' } \\
\text { S4021 - A18. W66 } \\
\text { S4021 - A19. W67' } \\
\text { S4021 - A20. W68 }\end{array}$ & $\begin{array}{l}\mathrm{NH}_{3} / \mathrm{NO}_{x} / \mathrm{H}_{2} \mathrm{O} \text { ( Sample } \# 1 \text { ) } \\
\mathrm{NH}_{3} / \mathrm{NO} / \mathrm{H}_{2} \mathrm{O} \text { (Sample } \# 2 \text { ) } \\
\mathrm{NH}_{3} / \mathrm{NO} / \mathrm{H}_{2} \mathrm{O} \text { (Sample } \# 3 \text { ) } \\
\left.\mathrm{NH}_{3} / \mathrm{NO}^{\prime} / \mathrm{H}_{2} \mathrm{O} \text { (Sample } \# 4\right) \\
\mathrm{NH}_{3} / \mathrm{NO}^{\prime} / \mathrm{H}_{2} \mathrm{O} \text { (Sample } \# 5 \text { ) }\end{array}$ \\
\hline $\begin{array}{l}\text { S4021 - A21. W69' } \\
\text { S4021 - A22. W70 }\end{array}$ & $\begin{array}{l}\mathrm{NH}_{3} \text { (Blank) } \\
\mathrm{NH}_{3} \text { (Splked Blank) }\end{array}$ \\
\hline $\begin{array}{l}\text { S4021-A23. W71' } \\
\text { S4021-A24. W72' } \\
\text { S4021-A25. W73' } \\
\text { S4021 - A26. W74' } \\
\text { S4021-A27. W75' }\end{array}$ & $\begin{array}{l}\mathrm{NO}_{x} / \mathrm{H}_{2} \mathrm{O} \text { (Sample \#1) } \\
\mathrm{NO} / \mathrm{H}_{2} \mathrm{O} \text { (Sample \#2) } \\
\mathrm{NO} / \mathrm{H}_{2} \mathrm{O} \text { (Sample \#3) } \\
\mathrm{NO} / \mathrm{H}_{2} \mathrm{O} \text { (Sample \#4) } \\
\mathrm{NO} \times / \mathrm{H}_{2} \mathrm{O} \text { (Sample \#5) }\end{array}$ \\
\hline $\begin{array}{l}\text { S4021 - A28. W76' } \\
\text { S4021 - A29. W77' }\end{array}$ & $\begin{array}{l}\text { NOx (Blank) } \\
\text { NOX ( Spiked Blank) }\end{array}$ \\
\hline $\begin{array}{l}\text { S4021-A30.W78 } \\
\text { S4021-A31. W79' }\end{array}$ & $\begin{array}{l}\mathrm{H}_{2} \mathrm{O} \text { ( Blank) } \\
\mathrm{H}_{2} \mathrm{O} \text { (Spiked Blank) }\end{array}$ \\
\hline
\end{tabular}

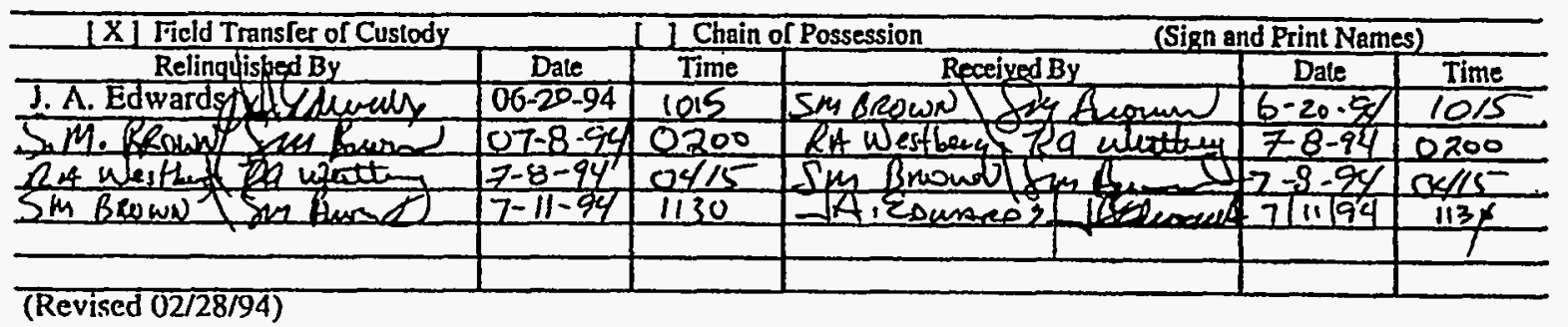

Final Sample Disposition

Disposnl Method:

A.6000.-407 (12/92) WERT6!

June 20. $1994 \bigcirc 9: 01$

Figure 1.1a Chain-of-Custody for Inorganic Samples from Tank BY-106 


\begin{tabular}{|c|c|c|}
\hline $\begin{array}{l}\text { Westinghouse } \\
\text { Hanford Company }\end{array}$ & CHAIN OF CUSTODY & WHC 006898 \\
\hline Custody Form Initiator & J. A. Edwards & $\begin{array}{rr}(509) 373 & -0141 \\
85.3009\end{array}$ \\
\hline Company Contact & R. A. Westberg & (509) $\quad 373-5734$ \\
\hline \multicolumn{2}{|c|}{$\begin{array}{l}\text { Project Designation/Sampling Locations } 200 \text { East Tank Farm } \\
241 \text {-BY-106 Tank Vapor Sample SAF S4021 } \\
\begin{array}{ll}\text { Ice Chest No. } & \text { (VSS Truck) }\end{array}\end{array}$} & $\begin{array}{l}06 \cdot-1-94 \\
06-19-94 \\
\text { WHC-N. }\end{array}$ \\
\hline Bill of Lading/Airbill No. & N/A & o. N/A \\
\hline Method of Shipment & Government Truck & \multirow[t]{2}{*}{ Sample Jọb \# } \\
\hline Shipped to & PNL & \\
\hline \multicolumn{3}{|c|}{ Possible Sample Hazards/Remarks Unknown at time of sampling } \\
\hline
\end{tabular}

Sample Identification

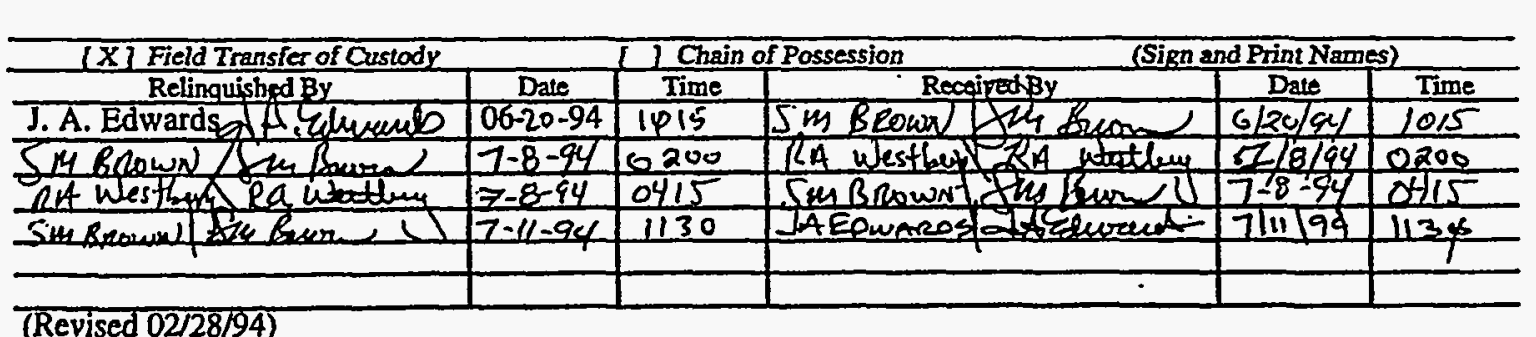

Final Sample Disposition

Disposal Method:

Disposed by:

DaterTime:

A.6000.407 (12/92) WEF061

Ambient Air SUMMA (PNL)

Ambient . SUMMA \#1 (PNL)

Sample SUMMA \#3 (PNL)

Sample SUMMA \#5 (PNL)

\begin{tabular}{|c|c|c|}
\hline$S 4021-A 01 . S 023$ & \multicolumn{2}{|c|}{ Ambient Air SUMMA (PNL) } \\
\hline $\mathrm{S} 4021$ - A02 . S024' & Ambient & SUMMA \#1 (PNL) \\
\hline $\begin{array}{l}\text { S4021 - A05 . S027' } \\
\text { S4021 - A07. S102' } \\
\text { S4021 - A09. S103 }\end{array}$ & $\begin{array}{l}\text { Sample } \\
\text { Sample } \\
\text { Sample }\end{array}$ & $\begin{array}{l}\text { SUMMA \#3 (PNL) } \\
\text { SUMMA \#5 (PNL) } \\
\text { SUMMA \#7 (PNL) }\end{array}$ \\
\hline
\end{tabular}

Figure 1.1b Chain-of-Custody for Organic Samples from Tank BY-106 



\subsection{Inorganic Task}

Solid sorbent traps, prepared in sampling trains, were supplied to WHC for sampling from the tank headspace using the VSS. Blanks, spiked blanks, and exposed samples were returned to PNL for analysis. Analyses were performed to provide information on the tank-headspace concentration of the following analytes: ammonia, nitrogen dioxide, nitric oxide, and water. Procedures were similar to those developed previously during sample jobs performed with the VSS connected to the tank headspace of Tank C-103 (Ligotke et al. 1994). Analytical accuracy was estimated based on procedures used. Sample preparation and analyses were performed following PNL quality assurance (QA) impact level (IL) III requirements.

\subsection{Standard Sampling Methodology}

Standard glass tubes containing sorbent materials to trap vapors of selected analytes from the group of $\mathrm{NH}_{3}, \mathrm{NO}_{x}$, and $\mathrm{H}_{2} \mathrm{O}$ (SKC Inc., Eighty Four, Pennsylvania) were obtained, prepared, and submitted for use by WHC. The sorbent traps were selected based on their use by the Occupational Safety and Health Administration (OSHA) to perform workplace monitoring, and because of available procedures and verification results associated with that particular application. The typical sorbent traps used consisted of a glass tube containing a sorbent material specific to the compound of interest. In general, the tubes contained two sorbent layers, or sections; the first layer was the primary trap, and the second layer provided an indication of breakthrough. In the tubes, sorbent layers are generally held in packed layers separated by glass wool. The sorbent tubes were received from the vendor having glass-sealed ends.

The type and nominal quantity of sorbent material varied by application. Sorbent traps selected for the tank sample job included the following. The $\mathrm{NH}_{3}$ sorbent traps contained carbon beads impregnated with sulfuric acid; nominally, $500 \mathrm{mg}$ were contained in the primary and $250 \mathrm{mg}$ in the breakthrough sections. The $\mathrm{NH}_{3}$ was chemisorbed as ammonium sulfate. The $\mathrm{NO}_{2}$ traps contained a zeolite impregnated with triethanolamine (TEA), with $400 \mathrm{mg}$ in the primary and $200 \mathrm{mg}$ in the breakthrough sections. The $\mathrm{NO}_{2}$ was absorbed and oxidized to equi-molar quantities of nitrite ions $\left(\mathrm{NO}_{2}{ }^{-}\right)$and nitrate ions $\left(\mathrm{NO}_{3}{ }^{-}\right)$. Glass tubes containing $800 \mathrm{mg}$ of an oxidant such as chromate were used to convert NO to $\mathrm{NO}_{2}$. The converted $\mathrm{NO}$ was then collected as nitrite and nitrate in a $\mathrm{NO}_{2}$ trap. The water traps contained $300 \mathrm{mg}$ of silica gel in the primary and $150 \mathrm{mg}$ in the breakthrough sorbent sections.

Samples provided by PNL to trap inorganic compounds include the following: samples, single-tube blanks, and spiked blanks. The samples of each type were prepared from same-lot batches, with the oxidizer sections of the $\mathrm{NO}_{x}$ sorbent trains having been stored previously in a freezer. After sample preparation, all samples, spiked samples, blanks, and spiked blanks were stored in a freezer, primarily because of handling recommendations for the oxidizer tubes attached to some samples. After receipt of exposed and radiologically cleared samples from WHC and disassembly of the sorbent trains, samples were provided to the analytical laboratory at ambient temperature, and selected oxidizer sections were returned to a freezer for possible subsequent use in laboratory method-validation studies.

The sorbent traps were prepared in 2-, 4-, or 5-trap sorbent trains configured so sample flow passed in order through the traps, targeting specific analytes, and then through a desiccant trap. The ends of the glass-tube traps were broken, and the traps were weighed and then connected to each other using uniform lengths of $3 / 8$-in. perfluoroalkoxy (PFA)-grade Teflon ${ }^{\circledR}$ tubing. The tubing was heated in hot air and forced over the open ends of the traps to form a tight seal. The inlets of the sorbent trains each consisted 
of a short section of tubing having a 3/8-in. stainless steel Swagelok nut, sealed using a cap. The trailing ends of the sorbent trains (the downstream end of the silica-gel tubes) were each sealed with red-plastic end caps provided by the manufacturer. The sorbent-tube trains remained sealed other than during the actual sampling periods. C-Flex tubing was provided by WHC to connect the downstream ends of the sorbent trains to the sampling exhaust-manifold connections.

2.1.1 Concentration Calculations. The concentrations of target compounds in the tank headspace were determined from sample results, assuming effective sample transport to the sorbent traps. Concentration, in parts-per-million by volume (ppmv), was determined by dividing the $\mu$ moles. of the compound by the moles of the sample. The micromolar compound mass was determined by dividing the compound mass, in $\mu \mathrm{g}$, by the molecular weight of the compound, in $\mathrm{g} / \mathrm{mol}$. The molar sample was determined, excluding water vapor, by dividing the standard sample volume (at $0^{\circ} \mathrm{C}$ and 760 torr), in $\mathrm{L}$, by $22.4 \mathrm{~L} / \mathrm{mol}$. For example, the concentration $\left(C_{v}\right)$ of a $3.00-\mathrm{L}$ sample containing $75.0 \mu \mathrm{g}$ of ammonia equals

$$
C_{\mathrm{v}}=\frac{75.0 \mu \mathrm{g}}{17 \mathrm{~g} / \mathrm{mol}} \times\left(\frac{3.00 \mathrm{~L}}{22.4 \mathrm{~L} / \mathrm{mol}}\right)^{-1}=32.9 \mathrm{ppmv}
$$

This calculational method produces concentration results that are slightly conservative (greater than actual) because the volume of water vapor in the sample stream is neglected. The volume of water vapor is not included in the measured sampled volume because of its removal in desiccant traps upstream of the mass flowmeters. However, the bias is generally expected to be small. For a tank-headspace temperature of $35^{\circ} \mathrm{C}$, the magnitude of the bias would be about 1 to $6 \%$, assuming tank-headspace relative humidities of 20 to $100 \%$, respectively. The concentration of mass (determined gravimetrically) was also per dry gas volume at standard conditions.

\subsection{Analytical Procedures}

The compounds of interest were trapped using solid sorbents and chemisorption. Analytical results were based on extraction and analysis of selected ions. Analytical procedures used are specified in the text. All were compiled in PNL-MA-599.

2.2.1 Ammonia Analysis. The sorbent material from the ammonia-selective sorbent tubes was placed into labeled $20-\mathrm{mL}$ glass scintillation vials. Vials containing front-, or primary-, section sorbent material were treated with $10.0 \mathrm{~mL}$ of deionized water (DIW), and vials containing back-up-section sorbent material were treated with $5.0 \mathrm{~mL}$ of DIW. After extraction, the aqueous solutions were analyzed using the selective ion electrode (SIE) procedure PNL-ALO-226 (Ammonia (Nitrogen) in Aqueous Samples . Briefly, this method includes 1) preparing a $1000-\mu \mathrm{g} / \mathrm{mL}(\mathrm{ppm}) \mathrm{NH}_{3}$ stock standard solution from dried reagent-grade $\mathrm{NH}_{4} \mathrm{Cl}$ and DIW on the day analyses are performed; 2) preparing 0.1-, 0.5-, 1.0-, 10-, and 100 -ppm $\mathrm{NH}_{3}$ working calibration standards by serial dilution of the freshly made stock standard; 3 ) generating an initial calibration curve from the measured electromotive force (emf) signal versus $\mathrm{NH}_{3}$ concentration data obtained for the set of working standards; 4) performing a calibration-verification check, using one of the midrange standards, after analyzing every four or five samples; 5) continuing this sequence until all samples of the batch have been measured, including duplicates and spiked samples; and 6) remeasuring the complete set of calibration standards at the end of the session. Emf signal measurements obtained for samples are compared to those for standards, either graphically or algebraically (using linear regression) to determine ammonia concentration in the samples. 
2.2.2 Nitrite Analysis. The sorbent traps for $\mathrm{NO}_{2}$ and $\mathrm{NO}$ were desorbed in an aqueous TEA and nbutanol solution and analyzed by suppressed-conductivity ion chromatography (SCIC) for nitrite according to PNL-ALO-212, Rev. 1 (Determination of Inorganic Anions by Ion Chromatography) and modified to obviate interferences by concentrations of non-target analytes. Specifically, the modifications used were 1) Eluent $1.44 \mathrm{mM} \mathrm{Na}_{2} \mathrm{CO}_{3}+1.8 \mathrm{mM} \mathrm{NaHCO}_{3}$ at $2.0 \mathrm{~mL} / \mathrm{min}$, 2) one guard column (AG4A) and two separator columns (AS4A) in series instead of just one separator column, and 3) all standards, samples, and blanks injected into the IC sample loop through $0.45-\mu \mathrm{m}$ syringe filters.

For the analysis, the sorbent materials were placed into labeled $20-\mathrm{mL}$ glass scintillation vials. To each vial, $3.0 \mathrm{~mL}$ of desorbing solution (15 g TEA $+1 \mathrm{~mL}$-butanol in $1.0 \mathrm{~L} \mathrm{DIW})$ was added. Primary sorbent-tube sample materials and back-up (breakthrough) sorbent-tube materials were analyzed separately using identical procedures. Each analytical session was conducted as follows. Working nitrite standards $(0,0.1,0.25$, and $0.5 \mathrm{ppm})$ were prepared by diluting a stock nitrite standard with desorbing solution. An initial calibration curve was prepared from the instrument response (chromatographic peak height) versus nitrite standard concentration data for the set of working standards. A calibration verification check using one of the midrange standards was performed after the analysis of every six samples. If the instrument response indicated that sample nitrite concentration was outside the calibration range ( $>0.5 \mathrm{ppm}$ nitrite), the sample was diluted with desorbing solution and reanalyzed. After all samples of a batch were analyzed, the complete set of calibration standards was remeasured to verify consistent instrument response, and the analytical session was terminated.

Instrument responses (peak height) observed for samples were compared to those for standards to determine the nitrite concentration of the samples. Because $\mathrm{NO}_{2}$ and $\mathrm{NO}$ converted to $\mathrm{NO}_{2}$ were collected on the sorbent as equal quantities of nitrite and nitrate, and the analysis was specific for nitrite, the molar masses of $\mathrm{NO}_{2}$ and $\mathrm{NO}$ were determined by doubling the analytically determined molar mass of nitrite.

2.2.3 Mass (Water) Analysis. Sorbent traps used to make each sample train were weighed using a semi-micro mass balance, after labeling and breaking the glass tube ends, without plastic end caps. After receipt of exposed samples, the sorbent traps were again weighed to determine the change in mass. Records of the measurements were documented on sample-preparation data sheets. The mass concentration, generally roughly equal to the concentration of water, was determined by dividing the combined change in mass from all traps in a sorbent train by the actual volume of gas sampled. Blanks and spiked blanks were included to provide information on uncertainty.

\subsection{Quality Assurance/Quality Control}

Analytical work was performed according to quality levels identified in the project QA plan and several PNL documents. PNL followed QA II III. The PNL documents include PNL-MA-70 (Part 2), PNL-MA-599, PNL-ALO-212, PNL-ALO-226, PNL-ALO-271, and MCS-033. A summary of the analysis procedures and limits for the target inorganic compounds is provided in Table 2.1. From the table, it can be seen that the minimum detection limit (MDL) required to resolve the analyte at one-tenth of the recommended exposure limit (REL) for each of the target analytes is achieved using current procedures and with a vapor-sample volume of $3 \mathrm{~L}$ and a desorption-solution volume of $3 \mathrm{~mL}(10 \mathrm{~mL}$ for ammonia). 
Table 2.1. Analysis Procedures and Detection Limits of Target Inorganic Analytes

\begin{tabular}{|c|c|c|c|c|c|}
\hline Analyte & Formula & Procedure & $\begin{array}{c}\mathrm{REL}^{(\mathrm{a})} \\
\text { (ppmv) }\end{array}$ & $\begin{array}{l}0.1 \times \mathrm{REL}^{(\mathrm{a})} \\
(\mathrm{ppmv})\end{array}$ & $\begin{array}{l}\mathrm{MDL}^{(b)} \\
\text { (ppmv) }\end{array}$ \\
\hline Ammonia & $\mathrm{NH}_{3}$ & PNL-ALO-226 & 25 & 2.5 & 0.5 \\
\hline Nitrogen dioxide & $\mathrm{NO}_{2}$ & PNL-ALO-212 & 1 & 0.1 & 0.02 \\
\hline Nitric oxide & $\mathrm{NO}^{2}$ & PNL-ALO-212 & 25 & 2.5 & 0.02 \\
\hline Mass (water) ${ }^{(\mathrm{c})}$ & $\mathrm{n} / \mathrm{a}$ & $\mathrm{n} / \mathrm{a}$ & $\mathrm{n} / \mathrm{a}$ & $\mathrm{n} / \mathrm{a}$ & $\mathrm{n} / \mathrm{a}$ \\
\hline
\end{tabular}

(a) Target analytical limits are equal to one-tenth of the REL.

(b) MDL is defined as the vapor concentration that can be detected with an uncertainty equal to about the magnitude of the measurement. The uncertainty is expected to reduce to about one-quarter of the magnitude of the measurement at a concentration of four times the MDL. The MDLs were based on the assumption that $3 \mathrm{~L}$ of vapor are sampled; if greater volumes of vapor are sampled, correspondingly smaller MDLs can be obtained. The MDLs were also based on desorbing-solution volumes of $10 \mathrm{~mL}$ for ammonia and $3 \mathrm{~mL}$ for the other analytes.

(c) The vapor mass concentration, thought to be largely water vapor, is determined for estimates of humidity.

The accuracy of concentration measurements depends on errors associated with both sampling and analysis. Sampling information was provided by WHC. The accuracy of analytical results depends on the method used. For ammonia analyses, the accuracy of laboratory measurements by selective ion electrode was estimated to be $\pm 5 \%$ relative, independent of concentration at $1 \mu \mathrm{g} / \mathrm{mL}$ or greater levels. The uncertainty includes preparation of standards, purity of the ammonium salt used to prepare standards, potential operator bias, ambient temperature variations, etc. Unfortunately, no known National Institute for Standards and Technology (NIST)-traceable standard reference material (SRM) is available against which to compare working standards. As for ammonia, no known NIST SRM is available for nitrite analysis (for $\mathrm{NO}_{2}$ and $\mathrm{NO}$ ). Based on experience in comparing nitrite working standards prepared from several different sources and factors mentioned for ammonia above, the estimated maximum bias for samples derived from sampling for $\mathrm{NO}_{2}$ is $\pm 10 \%$, and for samples derived from sampling for $\mathrm{NO}$, it is $\pm 5 \%$ relative. The accuracy of measurements of sample mass is $\pm 0.05 \mathrm{mg}$, or much less than $1 \%$ of the mass changes of samples, and roughly $5 \%$ or less of the mass change of blanks.

\subsection{Inorganic Sample Results}

Samples were obtained from the tank headspace of Tank BY-106 on 7/8/94 using the VSS. The sample job designation number was S4021. Samples were prepared, submitted to WHC, and then analyzed to provide information on the concentrations of ammonia, nitrogen dioxide, nitric oxide, and water. Sampling and analysis for hydrogen cyanide and sulfur oxides was not requested. Blank and spiked-blank samples were pooled with those provided for similar sampling jobs associated with Tank BY-104 (S4019) and Tank BY-105 (S4020). The inorganic samples were received from WHC on 7/11/94; the sample volume information was also received on 7/11/94.

A list of samples, sampling information, sample volumes, and gravimetric results is shown in Table 2.2. Percentage recovery results from spiked blanks are shown in Table 2.3. Analytical mass and concentration results are shown in Table 2.4. Sample volumes (Table 2.2) were provided by WHC; - sample-volume uncertainty was not provided. Tank-headspace concentration results (Table 2.4) are based 
Table 2.2. List of PNL Inorganic Samples and Gravimetric Results Obtained From a Heated Tube Inserted in the Tank Headspace of Tank BY-106 on 7/8/94. Blanks and spiked blanks were included from three similar sample jobs. Estimated sample information was provided by WHC.

\begin{tabular}{|c|c|c|c|c|c|c|}
\hline Sample & Type & $\begin{array}{c}\text { Sample } \\
\text { Port }\end{array}$ & $\begin{array}{l}\text { Planned } \\
\text { Flow Rate } \\
\text { (mL/min) }\end{array}$ & $\begin{array}{l}\text { Actual } \\
\text { Duration } \\
\text { (min) }\end{array}$ & $\begin{array}{l}\text { Sample } \\
\text { Volume }^{(a)} \\
\quad(L)\end{array}$ & $\begin{array}{l}\text { Mass } \\
\text { Gain } \\
(\mathrm{g})\end{array}$ \\
\hline S4021-A16-W64 & $\mathrm{NH}_{3} / \mathrm{NO}_{\mathrm{x}} / \mathrm{H}_{2} \mathrm{O}$ Sample & 8 & 200 & 15.0 & 3.00 & 0.0509 \\
\hline S4021-A17-W65 & $\mathrm{NH}_{3} / \mathrm{NO}_{x} / \mathrm{H}_{2} \mathrm{O}$ Sample & 10 & 200 & 15.0 & 3.00 & 0.0490 \\
\hline S4021-A18-W66 & $\mathrm{NH}_{3} / \mathrm{NO}_{\mathrm{x}} / \mathrm{H}_{2} \mathrm{O}$ Sample & 9 & 200 & 15.0 & 3.00 & 0.0516 \\
\hline S4021-A19-W67 & $\mathrm{NH}_{3} / \mathrm{NO}_{2} / \mathrm{H}_{2} \mathrm{O}$ Sample & 10 & 200 & 15.0 & 3.00 & 0.0501 \\
\hline S4021-A20-W68 & $\mathrm{NH}_{3} / \mathrm{NO}_{\mathrm{x}} / \mathrm{H}_{2}^{2} \mathrm{O}$ Sample & 8 & 200 & 15.0 & 3.00 & 0.0530 \\
\hline S4021-A23-W71 & $\mathrm{NO}_{\mathrm{x}} / \mathrm{H}_{2} \mathrm{O}$ Sample & 10 & 200 & 15.0 & 3.00 & 0.0478 \\
\hline S4021-A24-W72 & $\mathrm{NO}_{x} / \mathrm{H}_{2} \mathrm{O}$ Sample & 9 & 200 & $15.0^{\circ}$ & 3.00 & 0.0566 \\
\hline S4021-A25-W73 & $\mathrm{NO}_{\mathrm{x}} / \mathrm{H}_{2}^{2} \mathrm{O}$ Sample & 10 & 200 & 15.0 & 3.00 & $0.0343^{\text {(b) }}$ \\
\hline S4021-A26-W74 & $\mathrm{NO}_{\mathrm{x}} / \mathrm{H}_{2} \mathrm{O}$ Sample & 8 & 200 & 15.0 & 3.00 & 0.0516 \\
\hline S4021-A27-W75 & $\mathrm{NO}_{x}^{x} / \mathrm{H}_{2}^{2} \mathrm{O}$ Sample & 10 & 200 & 15.0 & 3.00 & 0.0473 \\
\hline S4019-A21-W37 & $\mathrm{NH}_{3}$ Blank & $n / a$ & $\mathrm{n} / \mathrm{a}$ & $\mathrm{n} / \mathrm{a}$ & $\mathrm{n} / \mathrm{a}$ & 0.0004 \\
\hline S4020-A21-W53 & $\mathrm{NH}_{3}^{2}$ Blank & $\mathrm{n} / \mathrm{a}$ & $\mathrm{n} / \mathrm{a}$ & $\mathrm{n} / \mathrm{a}$ & $\mathrm{n} / \mathrm{a}$ & 0.0022 \\
\hline S4021-A21-W69 & $\mathrm{NH}_{3}$ Blank & $\mathrm{n} / \mathrm{a}$ & $\mathrm{n} / \mathrm{a}$ & $\mathrm{n} / \mathrm{a}$ & $\mathrm{n} / \mathrm{a}$ & 0.0013 \\
\hline S4019-A28-W44 & $\mathrm{NO}_{2}^{2}$ - Blank & $\mathrm{n} / \mathrm{a}$ & $\mathrm{n} / \mathrm{a}$ & $\mathrm{n} / \mathrm{a}$ & $\mathrm{n} / \mathrm{a}$ & -0.0008 \\
\hline S4020-A28-W60 & $\mathrm{NO}_{2}^{-}$- Blank & $\mathrm{n} / \mathrm{a}$ & $\mathrm{n} / \mathrm{a}$ & $\mathrm{n} / \mathrm{a}$ & $\mathrm{n} / \mathrm{a}$ & 0.0025 \\
\hline S4021-A28-W76 & $\mathrm{NO}_{2}^{2}$ - Blank & $\mathrm{n} / \mathrm{a}$ & $\mathrm{n} / \mathrm{a}$ & $\mathrm{n} / \mathrm{a}$ & $\mathrm{n} / \mathrm{a}$ & 0.0008 \\
\hline S4019-A30-W46 & $\mathrm{H}_{2} \mathrm{O}$ Blank & $\mathrm{n} / \mathrm{a}$ & $\mathrm{n} / \mathrm{a}$ & $\mathrm{n} / \mathrm{a}$ & $\mathrm{n} / \mathrm{a}$ & 0.0005 \\
\hline $\mathrm{S} 4020-\mathrm{A} 30-\mathrm{W} 62$ & $\mathrm{H}_{2} \mathrm{O}$ Blank & $\mathrm{n} / \mathrm{a}$ & $\mathbf{n} / \mathbf{a}$ & $\mathrm{n} / \mathrm{a}$ & $\mathrm{n} / \mathrm{a}$ & 0.0016 \\
\hline S4021-A30-W78 & $\mathrm{H}_{2} \mathrm{O}$ Blank & $\mathrm{n} / \mathrm{a}$ & $\mathrm{n} / \mathrm{a}$ & $\mathrm{n} / \mathrm{a}$ & $\mathrm{n} / \mathrm{a}$ & -0.0001 \\
\hline S4019-A22-W38 & $\mathrm{NH}_{3}$ Spiked Blank & $\mathrm{n} / \mathrm{a}$ & $\mathrm{n} / \mathrm{a}$ & $\mathrm{n} / \mathrm{a}$ & $\mathrm{n} / \mathrm{a}$ & 0.0008 \\
\hline S4020-A22-W54 & $\mathrm{NH}_{3}$ Spiked Blank & $\mathrm{n} / \mathrm{a}$ & n/a & $\mathrm{n} / \mathrm{a}$ & $\mathrm{n} / \mathrm{a}$ & 0.0025 \\
\hline S4021-A22-W70 & $\mathrm{NH}_{3}$ Spiked Blank & $\mathrm{n} / \mathrm{a}$ & $\mathrm{n} / \mathrm{a}$ & $\mathrm{n} / \mathrm{a}$ & $n / a$ & 0.0015 \\
\hline S4019-A29-W45 & $\mathrm{NO}_{2}^{-}$Spiked Blank & $\mathrm{n} / \mathrm{a}$ & $\mathrm{n} / \mathrm{a}$ & $\mathrm{n} / \mathrm{a}$ & $\mathrm{n} / \mathrm{a}$ & 0.0006 \\
\hline S4020-A29-W61 & $\mathrm{NO}_{2}^{-}$Spiked Blank & $\mathrm{n} / \mathrm{a}$ & $\mathrm{n} / \mathrm{a}$ & $\mathrm{n} / \mathrm{a}$ & $\mathrm{n} / \mathrm{a}$ & 0.0023 \\
\hline S4021-A29-W77 & $\mathrm{NO}_{2}^{2}-$ Spiked Blank & $\mathrm{n} / \mathrm{a}$ & $\mathrm{n} / \mathrm{a}$ & $\mathrm{n} / \mathrm{a}$ & $\mathrm{n} / \mathrm{a}$ & 0.0010 \\
\hline S4019-A31-W47 & $\mathrm{H}_{2} \mathrm{O}$ Spiked Blank & $n / a$ & $n / a$ & $n / a$ & $\mathrm{n} / \mathrm{a}$ & 0.0005 \\
\hline S4020-A31-W63 & $\mathrm{H}_{2}^{2} \mathrm{O}$ Spiked Blank & $\mathrm{n} / \mathrm{a}$ & $\mathrm{n} / \mathrm{a}$ & $\mathrm{n} / \mathrm{a}$ & $\mathrm{n} / \mathrm{a}$ & 0.0020 \\
\hline S4021-A31-W79 & $\mathrm{H}_{2} \mathrm{O}$ Spiked Blank & $\mathrm{n} / \mathrm{a}$ & $\mathrm{n} / \mathrm{a}$ & $\mathrm{n} / \mathrm{a}$ & $\mathrm{n} / \mathrm{a}$ & 0.0013 \\
\hline
\end{tabular}

(a) Sample volumes were provided by WHC and were for dry gas at $0^{\circ} \mathrm{C}$ and 760 torr. Uncertainty values were not provided with sample volume results.

(b) Values excluded from the analysis of mass concentration. Loss of broken glass tube ends was the probable cause of less-than-typical mass results. Mass change of spiked blanks does not include the added mass of the spikes.

on this information, and the listed uncertainties equal plus-or-minus one standard deviation of the individual results from each set of samples. Sample results were not corrected for the percentage recoveries of spiked blanks.

2.4.1 Ammonia Results. The concentration of $\mathrm{NH}_{3}$ was $74 \pm 2 \mathrm{ppmv}$, based on all five samples. The mass of $\mathrm{NH}_{3}$ ranged from 9.7 to $10.5 \mu \mathrm{mol}$ in the front sorbent sections and was 0.03 in the two back sections that were analyzed. The MDL was $\leq 0.06 \mu \mathrm{mol}$ and was equivalent to a vapor concentration of $\leq 0.5$ ppmv. The mass of $\mathrm{NH}_{3}$ on the front and back sections of three blanks was $\leq 0.06 \mu \mathrm{mol}$, and thus, a blank correction was not significant. The percentage recovery of three blanks spiked with $12.2 \mu \mathrm{mol} \mathrm{NH}_{3}$ was $101 \pm 4 \%$. Past blanks spiked with 22.3 and $46.4 \mu \mathrm{mol}$ yielded percentage recoveries of $109 \pm 2$ and $104 \pm 1 \%$, respectively (Ligotke et al. 1994). One sample leachate was spiked after initial analysis with 
Table 2.3. Percentage Recovery Results of Inorganic Spiked Blanks Sent to the Field but not Opened During Sampling of Tanks BY-104, -105, and -106 in June and July, 1994. Spikes were applied to the center of front sorbent sections. Analysis of selected back sections yielded levels comparable to those found in the blanks.

Sample

Identifier

S4019-A22-W38

S4020-A22-W54

S4021-A22-W70

S4019-A29-W45

S4020-A29-W61

S4021-A29-W77

S4019-A31-W47

S4020-A31-W63

S4021-A31-W79

Tank
BY-104
BY-105
BY-106
BY-104
BY-105
BY-106
BY-104
BY-105
BY-106

\begin{tabular}{|c|c|c|c|c|}
\hline \multirow[b]{2}{*}{ Compound } & \multirow{2}{*}{$\begin{array}{c}\text { Spike } \\
\text { Added }^{(a)} \\
(\mu \mathrm{mol}) \\
\end{array}$} & \multirow{2}{*}{$\begin{array}{l}\text { Analytical } \\
\text { Result }^{(b)} \\
(\mu \mathrm{mol})\end{array}$} & \multicolumn{2}{|c|}{ Percentage Recovery } \\
\hline & & & $\begin{array}{c}\text { Sample } \\
(\%)\end{array}$ & $\begin{array}{l}\text { Average }^{(c)} \\
(\%)\end{array}$ \\
\hline $\mathrm{NH}_{3}$ & 12.4 & 13.2 & 106 & $101 \pm 4$ \\
\hline $\mathrm{NH}_{3}$ & 12.1 & 12.0 & 99 & \\
\hline $\mathrm{NH}_{3}$ & 12.2 & 12.0 & 98 & \\
\hline $\mathrm{NO}_{2}^{-}$ & 0.0472 & 0.0465 & 99 & $103 \pm 4$ \\
\hline $\mathrm{NO}_{2}^{2-}$ & 0.0463 & 0.0484 & 105 & \\
\hline $\mathrm{NO}_{2}^{-}$ & 0.0480 & 0.0508 & 106 & \\
\hline $\mathrm{H}_{2} \mathrm{O}$ & $2811^{(\mathrm{d})}$ & 2839 & 101 & $103 \pm 2$ \\
\hline $\mathrm{H}_{2}^{-} \mathrm{O}$ & 2856 & 2967 & 104 & \\
\hline $\mathrm{H}_{2}^{2} \mathrm{O}$ & 2878 & 2950 & 103 & \\
\hline
\end{tabular}

(a) The $\mathrm{NH}_{3}$ spike solutions were $20 \mu \mathrm{L}$ of $10,000 \mathrm{ppm}\left(3.142 \mathrm{~g} \mathrm{NH}_{4} \mathrm{Cl}\right.$ per $\left.100 \mathrm{~mL}\right)$. The $\mathrm{NO}_{2}$ spike solutions were $20 \mu \mathrm{L}$ of $100 \mathrm{ppm}$ nitrite. The $\mathrm{H}_{2} \mathrm{O}$ spike was $50 \mu \mathrm{L}$ of distilled water. The $\mu \mathrm{mol}$ of spiked material added were determined gravimetrically (e.g., $0.021 \mathrm{~g} \times 10,000 \mu \mathrm{g}$ $\left.\mathrm{NH}_{3} / \mathrm{mL} \div 17 \mathrm{~g} / \mathrm{mol}=12.4 \mu \mathrm{mol}\right)$.

(b) Blank corrections for $\mathrm{NH}_{3}$ analytical results were not significant. Analytical results for $\mathrm{NO}_{2}^{-}$ were corrected for blank levels, with each result corrected by the single blank associated with the tank.

(c) Summary results are listed as average recovery \pm 1 standard deviation.

(d) Water measured in $\mu \mathrm{g}$ and converted to $\mu \mathrm{mol}$ by dividing by the molecular weight of water (18).

roughly twice the mass of $\mathrm{NH}_{3}$ in the sample and yielded a percentage recovery of $98 \%$. The analysis of one sample was duplicated and yielded a repeatability of $\pm 1 \%$. A 5-point calibration was performed over an $\mathrm{NH}_{3}$ range of 0.1 to $1000 \mu \mathrm{g} / \mathrm{mL}$. The $\mathrm{NH}_{3}$ concentrations from samples from Ports 8 and 9 were not significantly different from those from Port 10.

2.4.2 Nitrogen Oxides Results. Measurements of $\mathrm{NO}_{2}$ and $\mathrm{NO}$ were made using $\mathrm{NH}_{3} / \mathrm{NO}_{\mathrm{x}} / \mathrm{H}_{2} \mathrm{O}$ and $\mathrm{NO}_{\mathrm{x}} / \mathrm{H}_{2} \mathrm{O}$ sorbent-trap trains (the $\mathrm{NO}_{\mathrm{x}}$ trains consisted of $\mathrm{NO}_{2}$ trap, oxidizer, $\mathrm{NO}_{2}$ trap). Five samples of each sample-train type were obtained. The presence of the upstream $\mathrm{NH}_{3}$ traps resulted in $\mathrm{NO}$ concentrations that were about 1.6-fold less than those from unprotected $\mathrm{NO}_{2}$ traps. The $\mathrm{NO}_{2}$ concentrations were also potentially less following an $\mathrm{NH}_{3}$ trap.

The concentration of $\mathrm{NO}_{2}$ was $\leq 0.04 \mathrm{ppmv}$ (the $\mathrm{MDL}$ ) from sorbent traps downstream of $\mathrm{NH}_{3}$ traps and $0.05 \pm 0.04 \mathrm{ppmv}$ from sorbent traps leading the sample trains. The concentration of NO was $0.10 \pm 0.05$ ppmv from sorbent traps downstream of $\mathrm{NH}_{3}$ traps and $0.16 \pm 0.06 \mathrm{ppmv}$ from sorbent traps leading the sample trains. Uncorrected $\mathrm{NO}_{2}{ }^{-}$quantities in the traps ranged from 0.014 to $0.029 \mu \mathrm{mol}$ in the front sorbent sections and 0.007 to $0.009 \mu \mathrm{mol}$ in the back sections. The $\mathrm{MDL}$ of $\mathrm{NO}_{2}{ }^{-}$was about $0.001 \mu \mathrm{mol}$. The $\mathrm{NO}_{2}{ }^{-}$content of three front and back blank sorbent sections was $0.016 \pm 0.002$ and $0.0087 \pm 0.0007 \mu \mathrm{mol}$, respectively, and these values were used to correct the quantity of $\mathrm{NO}_{2}{ }^{-}$measured in the samples. The percentage recovery of three blanks spiked with $0.047 \mu \mathrm{mol} \mathrm{NO}_{2}{ }^{-}$was $103 \pm 4 \%$. Past blanks spiked with $0.0064,0.11$, and $0.74 \mu \mathrm{mol} \mathrm{NO}{ }_{2}^{-}$yielded percentage recoveries of $153 \pm 14,106$ 
\pm 8 , and $111 \pm 7 \%$, respectively (Ligotke et al. 1994). No sample leachates were spiked after initial analysis with quantities of $\mathrm{NO}_{2}^{-}$to test analytical percentage recoveries. No samples were reanalyzed to check repeatability. A 4-point calibration was performed over a concentration range of 0 to $0.5 \mu \mathrm{NO}_{2}{ }^{-}$ per $\mathrm{mL}$ in the desorbing matrix.

2.4.3 Gravimetric Results. The mass concentration of material collected in the sorbent-trap trains, believed to be primarily water vapor, was $17 \pm 2 \mathrm{mg} / \mathrm{L}$. The result was based on an average mass gain of $0.509 \pm 0.028 \mathrm{~g}$ from 9 of 10 sets of $\mathrm{NH}_{3} / \mathrm{NO}_{2} / \mathrm{H}_{2} \mathrm{O}$ and $\mathrm{NO}_{\mathrm{x}} / \mathrm{H}_{2} \mathrm{O}$ sample trains. The percentage recovery of mass from three blank silica-gel traps spiked with $51 \mu \mathrm{g}$ water was $103 \pm 2 \%$. The six blank and spiked-blank traps generally gained mass, and ranged between -0.001 and 0.001 g gained per trap. Based on four traps per sample train, a blank correction would result in an additional uncertainty of \pm 1 $\mathrm{mg} / \mathrm{L}$. Although no blank correction was made, the total measurement uncertainty was determined as the sum of one standard deviation and the blank uncertainty. The mass gains of the samples obtained from Ports 8 and 9 averaged $8 \%$ greater than those of samples from Port 10 (the range was 1 to $16 \%$ more mass in samples from Ports 8 and 9). 
Table 2.4. Inorganic Vapor Sample Results Obtained From a Heated Tube Inserted in the Tank Headspace of Tank BY-106 on 7/8/94

\begin{tabular}{|c|c|c|c|c|c|}
\hline \multirow[b]{2}{*}{$\underline{\text { Sample }}$} & \multirow[b]{2}{*}{$\begin{array}{l}\text { Tank if Other } \\
\text { Than BY-106 }\end{array}$} & \multirow[b]{2}{*}{ Port } & \multicolumn{2}{|c|}{ Mass Collected } & \multirow{2}{*}{$\begin{array}{c}\text { Estimated }^{(\mathrm{a})} \\
\text { Concentration } \\
\text { (ppmv) }\end{array}$} \\
\hline & & & $\begin{array}{r}\text { Front } \\
(\mu \mathrm{mol}) \\
\end{array}$ & $\begin{array}{l}\text { Back } \\
(\mu \mathrm{mol})\end{array}$ & \\
\hline \multicolumn{5}{|l|}{$\mathrm{NH}_{3}$ Samples: } & $74 \pm 2^{(b)}$ \\
\hline S4021-A16-W64 & & 8 & 10.5 & 0.03 & \\
\hline S4021-A17-W65 & & 10 & 10.0 & $N A^{(c)}$ & \\
\hline S4021-A18-W66 & & 9 & 9.7 & 0.03 & \\
\hline S4021-A19-W67 & & 10 & 9.7 & NA & \\
\hline S4021-A20-W68 & & 8 & 9.9 & 0.03 & \\
\hline S4019-A21-W37 & BY-104 & blank & $\leq 0.06$ & $\leq 0.03$ & $\mathrm{n} / \mathrm{a}$ \\
\hline S4020-A21-W53 & BY-105 & blank & $\leq 0.06$ & 0.03 & $\mathrm{n} / \mathrm{a}$ \\
\hline S4021-A21-W69 & & blank & $\leq 0.06$ & $\leq 0.06$ & $\mathrm{n} / \mathrm{a}$ \\
\hline \multicolumn{6}{|l|}{$\mathrm{NO}_{2}^{-}$Blanks: } \\
\hline S4019-A28-W44 & BY-104 & blank & 0.0182 & 0.0095 & $\mathrm{n} / \mathrm{a}$ \\
\hline S4020-A28-W60 & BY-105 & blank & 0.0148 & 0.0082 & $\mathrm{n} / \mathrm{a}$ \\
\hline S4021-A28-W76 & & blank & 0.0148 & 0.0085 & $\mathrm{n} / \mathrm{a}$ \\
\hline \multirow{2}{*}{\multicolumn{5}{|c|}{$\mathrm{NO}_{2}$ Samples (Protected by $\mathrm{NH}_{3}$ sorbent trap): }} & $\leqq 0.04$ \\
\hline & & 8 & 0.0145 & 0.0069 & \\
\hline S4021-A17-W65 & & 10 & 0.0143 & 0.0078 & \\
\hline S4021-A18-W66 & & 9 & 0.0162 & 0.0073 & \\
\hline S4021-A19-W67 & & 10 & 0.0168 & 0.0081 & \\
\hline S4021-A20-W68 & & 8 & 0.0159 & 0.0081 & \\
\hline \multicolumn{5}{|c|}{$\mathrm{NO}_{2}$ Samples (Not Protected by $\mathrm{NH}_{3}$ sorbent trap): } & $\underline{0.05 \pm 0.04}$ \\
\hline S4021-A23-W71 & & 10 & 0.0191 & 0.0072 & \\
\hline S4021-A24-W72 & & 9 & 0.0187 & 0.0078 & \\
\hline S4021-A25-W73 & & 10 & 0.0198 & 0.0067 & \\
\hline S4021-A26-W74 & & 8 & 0.0192 & 0.0074 & \\
\hline S4021-A27-W75 & & 10 & 0.0196 & 0.0076 & \\
\hline \multicolumn{5}{|c|}{ NO Samples (Protected by $\mathrm{NH}_{3}$ sorbent trap): } & $\underline{0.10 \pm 0.05}$ \\
\hline S4021-A16-W64 & & 8 & 0.0235 & 0.0078 & \\
\hline S4021-A17-W65 & & 10 & 0.0225 & 0.0069 & \\
\hline S4021-A18-W66 & & 9 & 0.0215 & 0.0072 & \\
\hline S4021-A19-W67 & & 10 & 0.0215 & 0.0068 & \\
\hline S4021-A20-W68 & & 8 & 0.0247 & 0.0069 & \\
\hline \multicolumn{5}{|c|}{ NO Samples (Not Protected by $\mathrm{NH}_{3}$ sorbent trap): } & $\underline{0.16 \pm 0.06}$ \\
\hline S4021-A23-W71 & & 10 & 0.0252 & 0.0077 & \\
\hline S4021-A24-W72 & & 9 & 0.0248 & 0.0069 & \\
\hline S4021-A25-W73 & & 10 & 0.0264 & 0.0071 & \\
\hline S4021-A26-W74 & & 8 & 0.0274 & 0.0086 & \\
\hline S4021-A27-W75 & & 10 & 0.0290 & 0.0081 & \\
\hline
\end{tabular}

Gravimetric Samples:

$\underline{17 \pm 2 \mathrm{mg} / \mathrm{L}}$

(a) Blank-corrected concentrations were calculated using WHC-reported sample volumes at standard temperature and pressure (STP) $\left(0^{\circ} \mathrm{C}\right.$ and 760 torr), neglecting the 1 to $2 \%$ volume contribution of water vapor (condensed and collected before flow-rate measurement). Listed nitrite values were corrected for blank levels and doubled to account for unanalyzed nitrate. Mass concentration was determined per L of dry air at STP, based on 10 of 10 samples; no blank correction was made.

(b) Underlined values represent the average \pm 1 standard deviation for each set of samples.

(c) NA = not analyzed. Only selected back sorbent sections were analyzed. 


\subsection{Organic Task}

\subsection{SUMMA ${ }^{\mathrm{TM}}$ Canister Preparation}

Before sending SUMMA ${ }^{\mathrm{TM}}$ canisters out to the field for sampling, the canisters are cleaned and verified contaminant free according to PNL Technical Procedure PNL-TVP-02 ${ }^{(a)}$. The cleaning procedure uses an EnTech 3000 cleaning system that controls 1) filling the canisters with purified humid air and 2) evacuating, for several cycles with applied heat, before allowing the canister to evacuate overnight. The canister is filled a final time with purified humid air for analysis by PNL Technical Procedure PNL-TVP-01 ${ }^{(\mathrm{b})}$, which is a modification of U.S. Environmental Protection Agency (EPA) Compendium Method TO-14. If the canister is verified as clean, free of TO-14 contaminants to a level of $5 \mathrm{ppbv}$, the canister is evacuated to $30 \mathrm{in}$. $\mathrm{Hg}$, tagged, and stored for use in the field. Before sending the canisters out to the field for sampling, the canisters are prehumidified with $100 \mu \mathrm{L}$ of distilled water and labeled with a field sampling identification. Canisters not used after 30 days of storage are recleaned and validated before use.

\subsection{Sample Analysis Method}

SUMMATM canisters were analyzed according to PNL Technical Procedure PNL-TVP-03, Determination of TO-14 Volatile Organic Compounds in Hanford Waste Tank Headspace Samples Using SUMMA ${ }^{\mathrm{TM}}$ Passivated Canister Sampling and Gas Chromatographic-Mass Spectrometry Analysis, which is a modified version of EPA compendium Method TO-14. The method uses an EnTech cryoconcentration system interfaced with a Hewlett Packard (HP) 5971 GC/MS. The EnTech concentrator is used to pull a metered volume of sample air from the SUMMA ${ }^{\mathrm{TM}}$ canister, cryogenically concentrate the air volume, then transfer the volume to the GC/MS for analysis. A 100-mL volume of sample is measured and analyzed from the tank-headspace. The organic components in the sampled air are separated on an analytical column, J\&W Scientific DB- 1 phase, $60-\mathrm{m}$ by $0.32-\mathrm{mm}$ internal diameter with $3-\mu \mathrm{m}$ film thickness. The $\mathrm{GC}$ oven is programmed to run a temperature gradient beginning at $40^{\circ} \mathrm{C}$, holding for $5 \mathrm{~min}$, and ramping at $4^{\circ} \mathrm{C}$ per min to a final temperature of $260^{\circ} \mathrm{C}$, with a 5 -min hold.

\subsection{Quality Assurance/Quality Control}

Before the tank sample was analyzed, a diagnostic check was performed on the GC/MS instrument by running an instrument "quick tune," as described in PNL-TVP-03. Upon satisfactory completion of the instrument diagnostic check, a blank volume of purified nitrogen was analyzed to check the cleanliness of the system. The instrument was then calibrated over 6 data points ranging from $2 \mathrm{ppbv}$ to $100 \mathrm{ppbv}$, using a standard gas mixture containing 40 volatile organic compounds listed in EPA compendium Method TO-14. A gas mixture containing bromochloromethane, 1,4-difluorobenzene, and chlorobenzene- $\mathrm{d}_{5}$ was used as an internal standard (IS) for all blank, calibration standard, and sample analyses. Analyte response from sample components, ISs, and standards were obtained from the extracted ion plot from their selected mass ion. The calibration curve was generated by calculating the

(a) Pacific Northwest Laboratory. 8/94. Cleaning SUMMA ${ }^{\text {TM }}$ Canisters and the Validation of the Cleaning Process, PNL-TVP-02 (Rev. 0), PNL Technical Procedure, Richland, Washington.

(b) Pacific Northwest Laboratory. 8/94. Determination of TO-14 Volatile Organic Compounds in Ambient Air Using SUMMA TM Passivated Canister Sampling and Gas Chromatographic-Mass. Spectrometric Analysis, PNL-TVP-01 (Rev: 0). PNL Technical Procedure, Richland, Washington. 
relative response ratios of the IS to calibration standard responses and plotting the ratios against the ratio of the calibration-standard concentration (in ppbv) to the IS concentration. A least-squares linearregression routine was applied to the data set to generate the best-fit line for each compound. The equation for that line was then used to determine the concentration of positively identified compounds (PICs) seen in the tank samples.

3.3.1 Quantitation of TO-14 Results. The quantitative-analysis results for the TO-14 volatile organic compounds were calculated directly from the calibration curve generated using the IS method described above and in PNL-TVP-03. The conversion from $\mathrm{ppmv}$ to $\mathrm{mg} / \mathrm{m}^{3}$ assumes standard temperature and pressure (STP) conditions of 760 Torr and $273^{\circ} \mathrm{K}$ and was calculated directly from the following equation:

$$
\mathrm{mg} / \mathrm{m}^{3}=\frac{\text { ppmv } \times \text { molecular weight of compound }}{22.4}
$$

\subsubsection{Identification and Quantitation of Tentatively Identified Compounds. The TICs are} determined by mass spectral interpretation and comparison of the spectra with the EPA/NIST/WILEY Library, which is a part of the HP 5971 instrument operating system. Chromatographic peaks with an area count greater than, or equal to, one half of the total area count of the chlorobenzene- $d_{5}$ IS peak at the 20 -ppbv calibration level are tentatively identified and quantitatively estimated. This standard was chosen to determine the integration cutoff as it is in the middle of the chromatographic range and not in a region typically affected by coelution of other compounds. The quality of the mass spectral searches was then reviewed by the principal investigators before the identification was assigned to each chromatographic peak.

The concentration of each TIC was estimated using a relative response factor calculated using a corrected total peak area for the IS chlorobenzene- $d_{5}$. Specifically, the total integrated area for the chlorobenzene- $\mathrm{d}_{5}$ peak had to be corrected for possible coeluting compounds before calculating the response factor. The corrected total peak area for the IS was calculated by multiplying the IS quantitation ion by a correction factor based on the ratio of the total integrated peak area to the quantitation ion as measured in blank runs. The corrected peak area was then used to calculate a response factor using the IS concentration in $\mathrm{mg} / \mathrm{m}^{3}$ :

$$
\text { Response Factor }=\frac{I S \text { conc. }\left(\mathrm{mg} / \mathrm{m}^{3}\right)}{\text { IS peak area }}
$$

The calculated response factor was then multiplied by the TIC peak area to give an estimated concentration for that compound. For butane, the total peak area was multiplied by the response factor for chlorobenzene- $d_{5}$ to give an estimated concentration of $1.26 \mathrm{mg} / \mathrm{m}^{3}$ (for PNL 027). Internal standards bromochloromethane and difluorobenzene were not used to quantitate the TICs because coeluting compounds appeared to have greatly altered the signal of the quantitation ions for those two ISs. analyte.

The ppmv concentrations are calculated concentration from $\mathrm{mg} / \mathrm{m}^{3}$ and the molecular weight of the

$$
\text { TIC in ppmv }=\frac{\operatorname{TIC}\left(\mathrm{mg} / \mathrm{m}^{3}\right) \times 22.4}{\text { TIC mol. wt. }}
$$


The IS level added to all blank, standard, and sample injections was $18.3 \mathrm{ppbv}$ for bromochloromethane, $20.3 \mathrm{ppbv}$ for 1,4-difluorobenzene, and $18.2 \mathrm{ppbv}$ for chlorobenzene- $\mathrm{d}_{5}$. The IS concentrations were converted from $\mathrm{ppbv}$ to $\mathrm{mg} / \mathrm{m}^{3}$ at STP using a molecular weight of $129.39(\mathrm{~g} / \mathrm{mol})$ for bromochloromethane, 114.09 for 1,4-difluorobenzene, and 117.6 for chlorobenzene- $\mathrm{d}_{5}$.

\subsection{Analysis Results}

The results from the GC/MS analysis of the tank-headspace samples are presented in Tables 3.1 and 3.2. A representative total ion chromatogram showing the identity of major constituents is given in Figure 3.1.

Table 3.1 lists the quantitative results for compounds listed in Method TO-14. The levels of TO14 analytes observed in the samples collected from Tank BY-106 were similar to those seen in Tank BY-107. The most predominant TO-14 species seen in this sample were freon-11 (209 ppbv), freon 12 (14 ppbv), and toluene (7.5 ppbv). The other TO-14 compounds were at 4 ppbv or less.

Table 3.2 lists the semi-quantitative results for the TICs. The predominant species observed in these samples were 1-propene, 2-methyl-1-propene, butane, acetone, pentane, and butanol. As in previous tanks, the normal paraffin hydrocarbons $(\mathrm{NPH})$ defined as n-alkanes from $\mathrm{C}_{11}$ to $\mathrm{C}_{15}$ were present in the sample. However, in Tank BY-106, the NPH did not constitute the major portion of organic components seen. However, it should be noted that because the SUMMA ${ }^{\mathrm{TM}}$ canisters were not heated at the time of analysis, the NPH concentrations listed after the retention time of decane may not be a true accounting of all the NPH in the sample. Similarly, polar compounds, which may adhere to the inside surface of the canister, may also be under represented in this analysis. The total concentration of the TICs averaged $13.0 \mathrm{mg} / \mathrm{m}^{3}$ for three canisters analyzed. The estimated TIC concentration for one canister, S4021-A05-S027, totaled $17.6 \mathrm{mg} / \mathrm{m}^{3}$ while the estimated concentrations for the other two canisters amounted to 10.83 and $10.55 \mathrm{mg} / \mathrm{m}^{3}$. To date, nothing in the analytical procedure followed can account for this anomaly. The two SUMMA ${ }^{\mathrm{TM}}$ samples that were

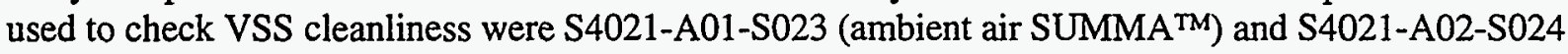
(ambient SUMMA ${ }^{\mathrm{TM}}$ No. 1). Comparison of the total ion chromatograms from the two samples showed the presence of minor constituents and no major differences. Minor constituents present were acetaldehyde, acetone, acetophenone, and benzothiazole. Table 3.3 shows the estimated concentration of these components. Further comparison with instrument blanks (high purity nitrogen) showed that benzothiazole was also present in the blanks. The source of this artifact may have come from the laboratory building since workers were re-tarring the roof at the time of analysis. 
. 


\subsection{Conclusions}

The concentrations of selected inorganic compounds were determined from samples of the tank headspace of Tank BY-106. The ammonia concentration was found to be $74 \pm 2 \mathrm{ppmv}$. The concentration of $\mathrm{NO}_{2}$ was $0.05 \pm 0.04 \mathrm{ppmv}$. The concentration of $\mathrm{NO}$ was $0.16 \pm 0.06 \mathrm{ppmv}$. The presence of an upstream $\mathrm{NH}_{3}$ sorbent trap resulted in samples yielding $\mathrm{NO}$ concentrations 1.6-fold less than those from unprotected samples. The $\mathrm{NO}_{2}$ concentrations were also potentially less following an $\mathrm{NH}_{3}$ trap. The vapor mass concentration, assumed to be largely water vapor, was $17 \pm 2 \mathrm{mg} / \mathrm{L}$. Although a slight difference was observed from mass change results, the more reliable ammonia measurements indicated the quantity of material collected in samples connected to Ports 8 and 9 was not significantly different from those connected to Port 10.

The concentration of selected organic compounds was determined from samples of the tank headspace of Tank BY-106. The total tentatively identified organic concentration for this tank was approximately $55 \%$ of the total seen in Tank BY-104. The decahydronaphthalene compounds seen in Tanks BY-107 and BY-108 were not observed in Tank BY-106. It should also be noted that while some NPH compounds were seen in this tank, the concentrations estimated were considerably lower than what has been calculated in other tank samples. See Figure 3.1 for the GC/MS chromatogram for Tank BY106.

\subsection{Reference}

Ligotke, M. W., K. H. Pool, and B. D. Lemer. 1994. Vapor Space Characterization of Waste Tank 241 C-103: Inorganic Results from Sample Job 7B (5/12/94 - 5/25/94). PNL-10172, Pacific Northwest Laboratory, Richland, Washington.

\subsection{Further Reading}

Pacific Northwest Laboratory. Analytical Laboratory Procedure Compendium. Procedures PNL-ALO212, -226, -271. PNL-MA-599, Richland, Washington.

Pacific Northwest Laboratory. Quality Assurance Manual, Part 2: Good Practices Standard. PNL-MA70, Part 2, Richland, Washington.

Pacific Northwest Laboratory. Quality Assurance Plan for Activities Conducted by the Analytical Chemistry Laboratory (ACL). MCS-033, Analytical Chemistry Laboratory, Richland, Washington.

Pacific Northwest Laboratory. 1994. Determination of TO-14 Volatile Organic Compounds in Hanford Waste Tank Headspace Samples Using SUMMATM Passivated Canister Sampling and Gas Chromatographic-Mass Spectrometry Analysis, PNL-TVP-03 (Rev. 0), PNL Technical Procedure, Richland, Washington. 
Table 3.1 TO-14 Analysis Results for Samples Collected from Hanford Waste Tank BY-106 in SUMMA ${ }^{\text {TM }}$ Canisters on 7/8/94

\begin{tabular}{|c|c|c|c|c|c|c|c|}
\hline \multirow[b]{2}{*}{ TO-14 Analytes } & \multirow[b]{2}{*}{ Cas. No. } & \multicolumn{2}{|c|}{$\begin{array}{l}\text { S4021-A05-S027(a) } \\
\text { PNL 027(b) }\end{array}$} & \multicolumn{2}{|c|}{$\begin{array}{l}\text { S4021-A07-S102 } \\
\text { PNL } 102^{(\mathrm{b})}\end{array}$} & \multicolumn{2}{|c|}{$\begin{array}{l}\text { S4021-A09-S103(a) } \\
\text { PNL } 103^{(b)}\end{array}$} \\
\hline & & (ppbv) & $\left(\mathrm{mg} / \mathrm{m}^{3}\right)^{(\mathrm{c})}$ & (ppbv) & $\left(\mathrm{mg} / \mathrm{m}^{3}\right)$ & (ppbv) & $\left(\mathrm{mg} / \mathrm{m}^{3}\right)$ \\
\hline $\begin{array}{l}\text { Dichlorodifluoromethane (FREON-12) } \\
\text { Methyl chloride (chloromethane) } \\
\text { I 2-Dichloro-1.1.2,2-tetrafluoroethane }\end{array}$ & $\begin{array}{l}75-71-8 \\
74-87-3\end{array}$ & $\begin{array}{r}13.50 \\
3.50\end{array}$ & $\begin{array}{l}0.07 \\
0.01\end{array}$ & $\begin{array}{r}10.26 \\
2.52\end{array}$ & $\begin{array}{l}0.06 \\
0.01\end{array}$ & $\begin{array}{l}9.86 \\
2.50\end{array}$ & $\begin{array}{l}0.05 \\
0.01\end{array}$ \\
\hline (FREON-114) & $76-14-2$ & $<2$ & $<.02$ & $<2$ & $<.02$ & $<2$ & $<.02$ \\
\hline Chloroethene (vinyl chloride) & $75-01-4$ & $<2$ & $<.006$ & $<2$ & $<.006$ & $<2$ & $<.006$ \\
\hline Methyl bromide (bromomethane) & $74-83-9$ & $<2$ & $<.009$ & $<2$ & $<.009$ & $<2$ & $<.009$ \\
\hline Ethyl chloride & $75-00-3$ & $<2$ & $<.006$ & $<2$ & $<.006$ & $<2$ & $<.006$ \\
\hline $\begin{array}{l}\text { Trichlorofluoromethane (FREON-11) } \\
\text { 1,1-Dichloroethene }\end{array}$ & $75-69-4$ & 209.18 & 1.28 & 180.12 & 1.10 & 176.70 & 1.08 \\
\hline $\begin{array}{l}\text { (1,1-Dichloroethylene) } \\
\text { Dichloromethane }\end{array}$ & $\begin{array}{l}75-35-4 \\
75-09-2\end{array}$ & $\begin{array}{l}<2 \\
<2\end{array}$ & $\begin{array}{l}<.009 \\
<.01\end{array}$ & $\begin{array}{l}<2 \\
<2\end{array}$ & $\begin{array}{l}<.009 \\
<.01\end{array}$ & $\begin{array}{l}<2 \\
<2\end{array}$ & $\begin{array}{l}<.009 \\
<.01\end{array}$ \\
\hline $\begin{array}{l}\text { 1,1,2-Trichloro-1,2,2-trifluoroethane } \\
\text { (FREON-113) }\end{array}$ & $76-13-1$ & $<2$ & $<.02$ & $<2$ & $<.02$ & $<2$ & $<.02$ \\
\hline 1,1-Dichloroethane & $75-34-3$ & $<2$ & $<.009$ & $<2$ & $<.009$ & $<2$ & $<.009$ \\
\hline cis-1,2-Dichloroethene & $156-60-5$ & $<2$ & $<.009$ & $<2$ & $<.009$ & $<2$ & $<.009$ \\
\hline $\begin{array}{l}\text { Trichloromethane (chloroform) } \\
\text { cis 1,2-Dichloroethane }\end{array}$ & $\begin{array}{r}67-66-3 \\
107-06-2\end{array}$ & $\begin{array}{l}<2 \\
<2\end{array}$ & $\begin{array}{l}<.01 \\
<.009\end{array}$ & $\begin{array}{l}<2 \\
<2\end{array}$ & $\begin{array}{l}<.01 \\
<.009\end{array}$ & $\begin{array}{l}<2 \\
<2\end{array}$ & $\begin{array}{l}<.01 \\
<.009\end{array}$ \\
\hline 1,1,1-Trichloroethane & $71-55-6$ & $<2$ & $<.01$ & $<2$ & $<.01$ & $<2$ & $<.01$ \\
\hline Benzene & $71-43-2$ & 2.72 & 0.01 & 2.00 & 0.01 & 2.00 & 0.01 \\
\hline Carbon Tetrachloride & $56-23-5$ & $<2$ & $<.01$ & $<2$ & $<.01$ & $<2$ & $<.01$ \\
\hline 1,2-Dichloropropane & $78-87-5$ & $<2$ & $<.01$ & $<2$ & $<.01$ & $<2$ & $<.01$ \\
\hline Trichloroethylene & 79-01-6 & $<2$ & $<.01$ & $<2$ & $<.01$ & $<2$ & $<.01$ \\
\hline cis 1,3-Dichloropropene & $10061-01-5$ & $<2$ & $<.01$ & $<2$ & $<.01$ & $<2$ & $<.01$ \\
\hline trans 1,3-Dichloropropene & $10061-02-6$ & $<2$ & $<.01$ & $<2$ & $<.01$ & $<2$ & $<.01$ \\
\hline 1,1,2-Trichloroethane & $79-00-5$ & $<2$ & $<.01$ & $<2$ & $<.01$ & $<2$ & $<.01$ \\
\hline Methyl benzene (toluene) & $108-88-3$ & 7.47 & 0.03 & 6.83 & 0.03 & 7.00 & 0.03 \\
\hline 1,2-Dibromoethane & $106-93-4$ & $<2$ & $<.02$ & $<2$ & $<.02$ & $<2$ & $<.02$ \\
\hline Tetrachloroethene) & $127-18-4$ & 3.75 & 0.03 & 2.00 & 0.01 & 4.00 & 0.03 \\
\hline Chlorobenzene & $108-90-7$ & $<2$ & $<.01$ & $<2$ & $<.01$ & $<2$ & $<.01$ \\
\hline Ethylbenzene & $100-41-4$ & 1.33 & 0.01 & $<2$ & $<.01$ & $<2$ & $<.01$ \\
\hline m-Xylene (1,3-dimethylbenzene) & $108-38-3$ & 3.55 & 0.02 & 2.75 & 0.01 & 3.00 & 0.01 \\
\hline p-Xylene (1,4-Dimethylbenzene) & $106-42-3$ & 3.55 & 0.02 & 2.75 & 0.01 & 3.00 & 0.01 \\
\hline Styrene & $100-42-5$ & $<2$ & $<.01$ & $<2$ & $<.01$ & $<2$ & $<.01$ \\
\hline 1,1,2,2-Tetrachloroethane & $79-34-5$ & $<2$ & $<.01$ & $<2$ & $<.01$ & $<2$ & $<.01$ \\
\hline o-Xylene (1,2-dimethylbenzene) & $95-47-6$ & $<2$ & $<.01$ & $<2$ & $<.01$ & $<2$ & $<.01$ \\
\hline 1,3,5-Trimethylbenzene & $108-67-8$ & $<2$ & $<.01$ & $<2$ & $<.01$ & $<2$ & $<.01$ \\
\hline 1,2,4-Trimethylbenzene & $95-63-6$ & $<2$ & $<.01$ & $<2$ & $<.01$ & $<2$ & $<.01$ \\
\hline Chloromethylbenzene & $100-44-7$ & $<2$ & $<.01$ & $<2$ & $<.01$ & $<2$ & $<.01$ \\
\hline m-Dichlorobenzene & $541-73-1$ & $<2$ & $<.01$ & $<2$ & $<.01$ & $<2$ & $<.01$ \\
\hline p-Dichlorobenzene & $106-46-7$ & $<2$ & $<.01$ & $<2$ & $<.01$ & $<2$ & $<.01$ \\
\hline o-Dichlorobenzene & $95-50-1$ & $<2$ & $<.01$ & $<2$ & $<.01$ & $<2$ & $<.01$ \\
\hline 1,2,4-Trichlorobenzene & $120-82-1$ & $<2$ & $<.02$ & $<2$ & $<.02$ & $<2$ & $<.02$ \\
\hline Hexachloro-1,3-butadiene & $87-68-3$ & $<2$ & $<.02$ & $<2$ & $<.02$ & $<2$ & $<.02$ \\
\hline
\end{tabular}
(a) WHC ID number.
(b) PNL SUMMA ${ }^{\mathrm{TM}}$ canister number.
(c) Calculated from ppbv using molecular weight of compound, $760 \mathrm{~mm}$ torr, and $0^{\circ} \mathrm{C}$. 


\begin{tabular}{|c|c|c|c|c|c|c|c|c|}
\hline $\begin{array}{l}20^{\circ} 0 \\
\text { (8) } \\
20^{\circ} 0 \\
10^{\circ} 0 \\
70^{\circ} 0 \\
10^{\circ} 0 \\
50^{\circ} 0 \\
20^{\circ} 0\end{array}$ & $\begin{array}{l}I I^{\circ}(8) \\
\text { (8) } \\
\tau I^{\circ} 0 \\
90^{\circ} 0 \\
\varepsilon \varepsilon^{\circ} 0 \\
90^{\circ} 0 \\
\forall \tau^{\circ} 0 \\
\varepsilon I^{\circ} 0\end{array}$ & $\begin{array}{l}20^{\circ} 0 \\
10^{\circ}> \\
20^{\circ} 0 \\
10^{\circ} 0 \\
20^{\circ} 0 \\
10^{\circ} 0 \\
50^{\circ} 0 \\
\varepsilon 0^{\circ} 0\end{array}$ & 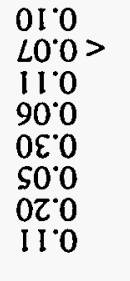 & $\begin{array}{l}20^{\circ} 0 \\
10^{\circ}> \\
\varepsilon 0^{\circ} 0 \\
10^{\circ} 0 \\
\angle 0^{\circ} 0 \\
10^{\circ} 0 \\
50^{\circ} 0 \\
\varepsilon 0^{\circ} 0\end{array}$ & $\begin{array}{l}I I^{\circ} 0 \\
\angle 0^{\circ} 0>> \\
I I^{\circ} 0 \\
S 0^{\circ} 0 \\
2 \varepsilon^{\circ} 0 \\
90^{\circ} 0 \\
2 Z^{\circ} 0 \\
\varepsilon I^{\circ} 0\end{array}$ & $\begin{array}{l}\varepsilon 0^{\circ} 0 \\
10^{\circ} 0 \\
\varepsilon 0^{\circ} 0 \\
20^{\circ} 0 \\
60^{\circ} 0 \\
10^{\circ} 0 \\
\angle 0^{\circ} 0 \\
\square 0^{\circ} 0\end{array}$ & $\begin{array}{l}E I^{\circ} 0 \\
\angle 0^{\circ} 0 \\
\forall I^{\circ} 0 \\
\angle 0^{\circ} 0 \\
8 E^{\circ} 0 \\
\angle 0^{\circ} 0 \\
6 Z^{\circ} 0 \\
9 I^{\circ} 0\end{array}$ & 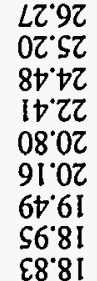 \\
\hline $\begin{array}{l}\varepsilon I^{\circ} 0 \\
I 0^{\circ} 0 \\
20^{\circ} 0 \\
80^{\circ} 0\end{array}$ & $\begin{array}{l}66^{\circ} 0 \\
\angle 0^{\circ} 0 \\
\angle 1^{\circ} 0 \\
D S^{\circ} 0\end{array}$ & $\begin{array}{l}82^{\circ} 0 \\
20^{\circ} 0 \\
\text { S0.0 } \\
\mathcal{E} 1^{\circ} 0\end{array}$ & $\begin{array}{l}68^{\circ} 0 \\
\angle 0^{\circ} 0 \\
5 I^{\circ} 0 \\
80^{\circ} 0\end{array}$ & $\begin{array}{l}0 \varepsilon^{\circ} 0 \\
Z 0^{\circ} 0 \\
\text { So'0 } \\
\text { El } 0\end{array}$ & $\begin{array}{l}960^{\circ} \\
\angle 0^{\circ} 0 \\
\angle I^{\circ} 0 \\
I S^{\circ} 0\end{array}$ & $\begin{array}{l}\text { SE.0 } \\
Z 0^{\circ} 0 \\
90^{\circ} 0 \\
\angle I^{\circ} 0\end{array}$ & $\begin{array}{l}\varepsilon I^{\circ} \mathrm{I} \\
60^{\circ} 0 \\
6 I^{\circ} 0 \\
t 9^{\circ} 0\end{array}$ & $\begin{array}{l}E 8^{\circ} L \mathrm{LI} \\
98^{\circ} 91 \\
\forall I^{\circ} 91\end{array}$ \\
\hline $\begin{array}{l}20^{\circ} 0 \\
10^{\circ} 0 \\
\varepsilon 0^{\circ} 0 \\
t 0^{\circ} 0 \\
90^{\circ} 0 \\
\text { (8) } \\
(8) \\
(8) \\
t 0^{\circ} 0 \\
11^{\circ} 0 \\
(8) \\
90^{\circ} 0 \\
t 0^{\circ} 0 \\
(8) \\
\angle 0^{\circ} 0 \\
S \varepsilon^{\circ} 0 \\
\angle Z^{\circ} 0 \\
t Z^{\circ} 0 \\
t 0^{\circ} 0 \\
10^{\circ} 0 \\
t I^{\circ} 0 \\
81^{\circ} 0 \\
(J) \\
(1)\end{array}$ & $\begin{array}{c}S I^{\circ} 0 \\
+I^{\circ} 0 \\
\angle I^{\circ} 0 \\
\angle I^{\circ} 0 \\
I L^{\circ} 0 \\
(8) \\
(8) \\
(8) \\
S L^{\circ} 0 \\
S 2^{\circ} 0 \\
(8) \\
88^{\circ} 0^{\circ} \\
60^{\circ} 0 \\
(8) \\
91^{\circ} 0 \\
98^{\circ} 0 \\
8 L^{\circ} 0 \\
95^{\circ} 0 \\
\angle 1^{\circ} 0 \\
90^{\circ} 0 \\
89^{\circ} 0 \\
70^{\circ} 1 \\
(J) \\
(J)\end{array}$ & $\begin{array}{l}\varepsilon 0^{\circ} 0 \\
\varepsilon 0^{\circ} 0 \\
S 0^{\circ} 0 \\
t 0^{\circ} 0 \\
0 Z^{\circ} 0 \\
Z 0^{\circ} 0> \\
Z 0^{\circ} 0> \\
20^{\circ} 0^{\circ}> \\
\phi I^{\circ} 0 \\
\angle 0^{\circ} 0 \\
\varepsilon 0^{\circ} 0> \\
\varepsilon Z^{\circ} 0 \\
20^{\circ} 0 \\
t 0^{\circ} 0> \\
S 0^{\circ} 0 \\
t Z^{\circ} 0 \\
I Z^{\circ} 0 \\
t I^{\circ} 0 \\
\angle 0^{\circ} 0 \\
\varepsilon 0^{\circ} 0 \\
0 E^{\circ} 0 \\
8 S^{\circ} 0 \\
(J) \\
(\mathrm{J})\end{array}$ & 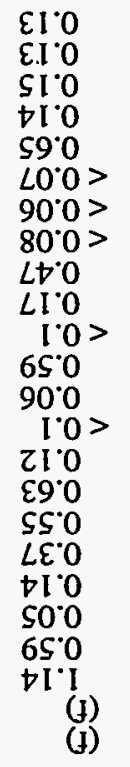 & 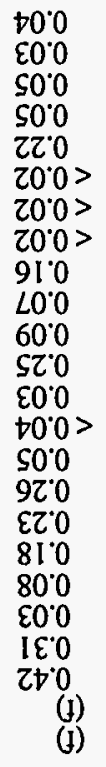 & $\begin{array}{l}D I^{\circ} 0 \\
\varepsilon I^{\circ} 0 \\
L I^{\circ} 0 \\
S I^{\circ} 0 \\
69^{\circ} 0 \\
L 0^{\circ} 0> \\
80^{\circ} 0> \\
90^{\circ} 0> \\
\varepsilon 5^{\circ} 0 \\
6 I^{\circ} 0 \\
E 7^{\circ} 0 \\
t 9^{\circ} 0 \\
L 0^{\circ} 0 \\
I^{\circ} 0> \\
\varepsilon I^{\circ} 0 \\
89^{\circ} 0 \\
09^{\circ} 0 \\
\angle 7^{\circ} 0 \\
S I^{\circ} 0 \\
90^{\circ} 0 \\
19^{\circ} 0 \\
\varepsilon 8^{\circ} 0 \\
(\mathrm{~J}) \\
(\mathrm{J})\end{array}$ & 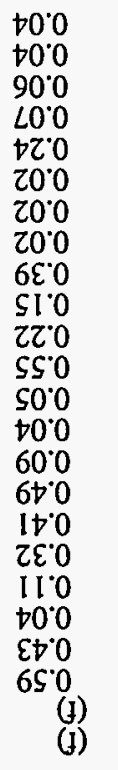 & 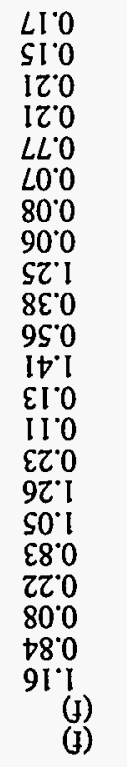 & 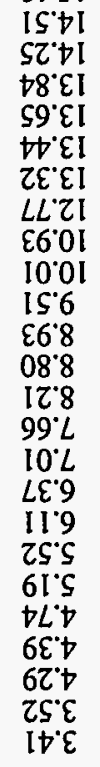 \\
\hline 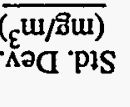 & 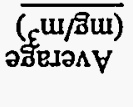 & 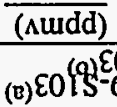 & $\frac{\overline{(\mathrm{c} w / \delta \mathrm{g} w)}}{\mathrm{Nd}}$ & $\frac{\text { (Auidd) }}{z 01 S^{-} L}$ & 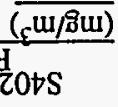 & $\frac{\text { (Audd) }}{(\mathrm{e}) \angle \mathcal{C O S S ^ { - }}}$ & $\frac{c w / 3 w)}{20 t S}$ & 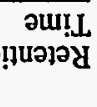 \\
\hline
\end{tabular}

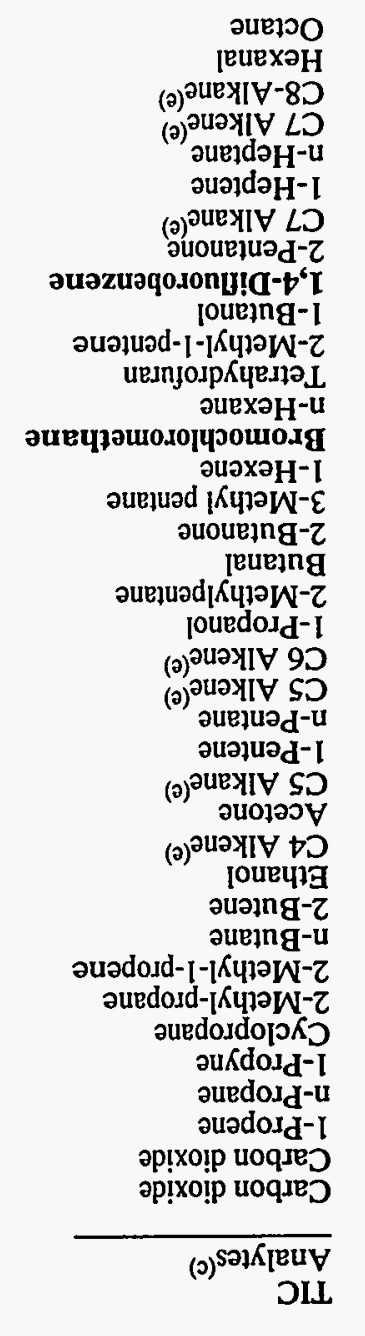

$76 / 8 / L$ uo paijo⿰l0

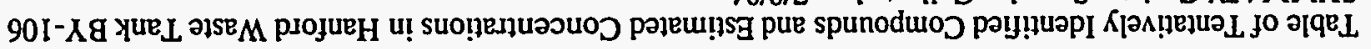


Table 3.2 Contd

TIC

Analytes $^{(\mathrm{c})}$

Chlorobenzene-d5

2-Butoxyethanol

C10 Alkane (e)

Cl0 Alkane

Phenol ${ }^{(e)}$

C11 Alkane

$n$-Undecane

n-Dodecane

N Benzothiazole (impurity)

C7 Cyclohexane

C13 Alkane ${ }^{(e)}$

n-Tridecane

C13 Alkane(e)

C13 Alkane (e) $^{(\mathrm{e}}$

\begin{tabular}{l} 
Retention \\
Time \\
\hline \\
\\
\\
30.93 \\
31.37 \\
33.15 \\
33.79 \\
36.08 \\
40.41 \\
44.44 \\
45.07 \\
45.67 \\
46.52 \\
47.33 \\
48.18 \\
51.06 \\
51.69
\end{tabular}

S4021-A05-S027 (a)
PNL 027

$\left(\overline{\left.\mathrm{mg} / \mathrm{m}^{3}\right)^{(\mathrm{d})}}\right.$ (ppmv)

\subsection{6}

0.06

0.07

0.05

0.05
0.05
0.06
0.09

0.09

0.08

0.06

0.06

0.06
0.11
0.07

0.11
0.07

0.06
S4021-A07-S102

$\frac{\text { PNL } 102}{\left(\mathrm{mg} / \mathrm{m}^{3}\right)}$

(ppmv)

\begin{tabular}{l} 
S4021-A09-S103(a) \\
PNL 103 \\
$\frac{\left(\mathrm{mg} / \mathrm{m}^{3}\right)}{(\mathrm{ppmv})}$ \\
\hline
\end{tabular}

Average

$\underline{\left(\mathrm{mg} / \mathrm{m}^{3}\right)}$

Std. Dev.

$\underline{\left(\mathrm{mg} / \mathrm{m}^{3}\right)}$

$\begin{array}{lrrrr}0.01 & <0.06 & <.01 & <0.06 & <.01 \\ 0.01 & 0.06 & 0.01 & 0.05 & 0.01 \\ 0.01 & <0.1 & <.02 & <0.1 & <.02 \\ 0.01 & <0.1 & <.02 & <0.1 & <.02 \\ 0.01 & <0.05 & <.01 & <0.05 & <.01 \\ 0.01 & 0.05 & 0.01 & <0.1 & <.02 \\ 0.01 & 0.09 & 0.01 & 0.08 & 0.01 \\ 0.01 & 0.07 & 0.01 & 0.07 & 0.01 \\ 0.01 & <0.05 & <.01 & <0.05 & <.01 \\ 0.01 & <0.05 & <.01 & <0.05 & <.01 \\ 0.01 & 0.07 & 0.01 & 0.06 & 0.01 \\ 0.01 & 0.08 & 0.01 & 0.09 & 0.01 \\ 0.01 & 0.05 & 0.01 & 0.05 & 0.01 \\ 0.01 & <0.05 & <.01 & <0.05 & <.01\end{array}$

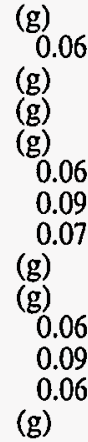

(g)

(g)

(g)

(g) 0.00

0.01

0.01

(g)

(g)

0.01

0.01

(g)

\footnotetext{
(a) WHC sample number.

(b) PNL SUMMATM canister number.

(c) Obtained by mass spectral interpretation and comparison with the EPA/NIST/WILEY Library.

(d) Semi-quantitative estimate calculated using concentration of the chlorobenzene- $\mathrm{d}_{5}$.

(e) Other structural isomers should be considered.

(f) Carbon dioxide is not quantifiable due to the analytical method used.

(g) Molecular weight infomration is not available for this TIC.
} 
Table 3.3 Estimated Concentrations in Ambient SUMMA ${ }^{\mathrm{TM}}$ Canister Samples Taken for VSS Cleanliness Comparison

\begin{tabular}{|c|c|c|c|c|}
\hline TIC Analytes & $\begin{array}{c}\text { Mol Wt } \\
\text { (gram/mole) }\end{array}$ & $\begin{array}{c}\text { S4021-A01-S024 } \\
\text { Ambient Air } \\
\text { ppmv } \\
\end{array}$ & $\begin{array}{c}\text { S4021-A02-S023 } \\
\text { VSS SUMMA TM No. } 1 \\
\text { (ppmv) } \\
\end{array}$ & $\begin{array}{c}\text { Nitrogen } \\
\text { Instrument } \\
\text { (ppmv) } \\
\end{array}$ \\
\hline Acetaldehyde & 44 & 0.031 & 0.058 & (a) \\
\hline Acetone & 58 & 0.041 & 0.072 & (a) \\
\hline Acetophenone & 120 & 0.005 & 0.011 & (a) \\
\hline Benzothiazole & 135 & 0.009 & 0.006 & 0.002 \\
\hline
\end{tabular}




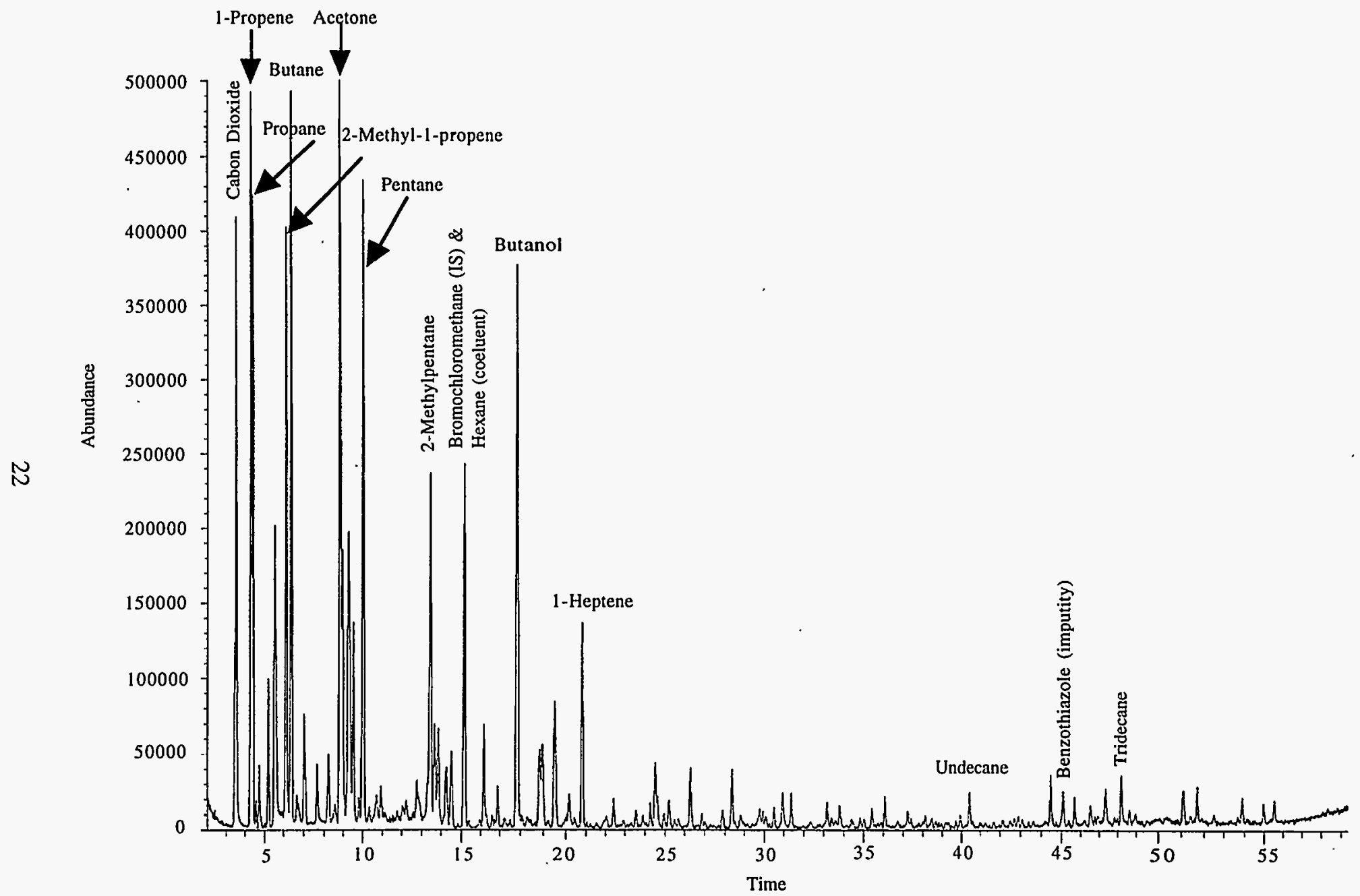

Figure 3.1 GC/MS Chromatogram of Hanford Waste Tank BY-106 SUMMA ${ }^{\text {TM }}$ Canister Vapor Sample S4021-A05-027 Collected Through the WHC Vapor Sampling System on 7/8/94 


\section{Distribution}

No. of Copies

Offsite

2 DOE/Office of Scientific and Technical Information

R. A. Jenkins

Oak Ridge National Laboratory

P.O. Box 2008

Building 4500-5, MS 6120

Oak Ridge, Tennessee 37831-6120

B. C. Kowalski

CPAC

University of Washington

MS BG-10

Seattle, Washington 98195
No. of Copies

Onsite

2 DOE Richland Operations Office

M. F. Jarvis, S7-54

C. Babel, S7-54

Corps of Engineers

T. W. Gardner-Clayson, A5-19

10 Westinghouse Hanford Company

H. Babad, R2-78

D. R. Bratzel, S7-31 (2)

S. J. Eberlien, R2-12

T. J. Kelley, S7-30

E. R. Hewitt, R3-01

N. W. Kirch, R2-11

E. J. Lipke, S7-14

J. E. Meacham, S7-15

B. C. Simpson, R2-12

20 Pacific Northwest Laboratory

T. W. Clauss, P8-08

K. H. Pool, P8-44

B. L. Thomas, K9-25

B. D. McVeety, K6-84

K. B. Olsen, K6-96

J. S. Fruchter, K6-96

S. C. Goheen, P8-08

M. W. Ligotke P7-59 (6)

J. L. Huckaby, K6-55

K. L. Silvers, P7-27

Technical Report Files (5)

Dist. 1 